Portland State University

PDXScholar

$1-19-1990$

\title{
DNA Fingerprinting Analysis of Captive Asian Elephants, Elephas maximas
}

Laura Louise Bischof

Portland State University

Follow this and additional works at: https://pdxscholar.library.pdx.edu/open_access_etds

Part of the Animal Sciences Commons, and the Biology Commons Let us know how access to this document benefits you.

\section{Recommended Citation}

Bischof, Laura Louise, "DNA Fingerprinting Analysis of Captive Asian Elephants, Elephas maximas" (1990). Dissertations and Theses. Paper 3966.

https://doi.org/10.15760/etd.5850

This Thesis is brought to you for free and open access. It has been accepted for inclusion in Dissertations and Theses by an authorized administrator of PDXScholar. Please contact us if we can make this document more accessible: pdxscholar@pdx.edu. 
AN ABSTRACT OF THE THESIS OF Laura Louise Bischof for the

Master of Science in Biology presented January 19, 1990.

Title: DNA Fingerprinting Analysis of Captive Asian Elephants, Elephas maximas.

APPROVED BY THE MEMBERS OF THE THESIS COMMITTEE:

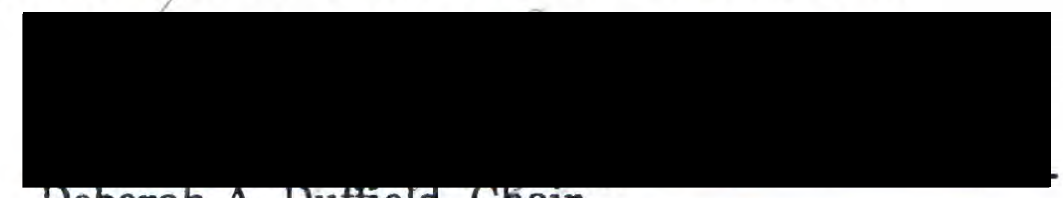

Deborah A. Duftield, Chair

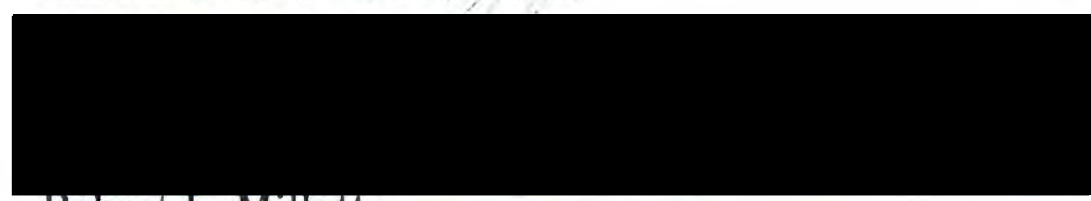

Robert L. Millette

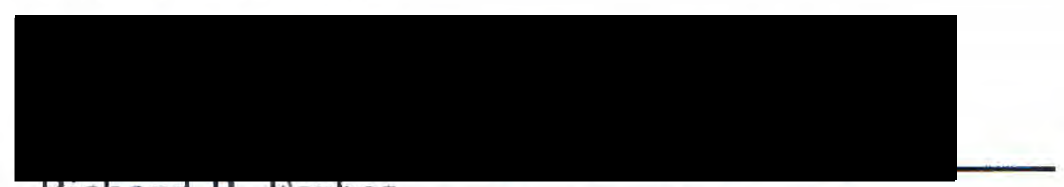

Richard B. Forbes

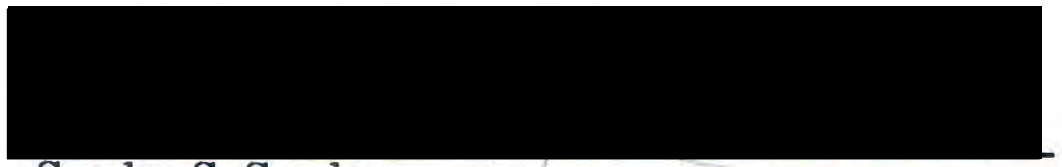

Sandra S. Snyder

This thesis examined the effectiveness of DNA fingerprinting analysis for paternity ascertainment and the establishment of relatedness of captive Asian elephants (Elephas maximas). Eighteen Asian elephants from three North American zoos were examined. Thirteen of these elephants were wild caught. Relationships between these elephants and the remaining elephants born in captivity were known. 
DNA was extracted from blood samples, cleaved with restriction endonucleases, and separated by horizontal gel electrophoresis. The DNA was then transferred to a nylon membrane and fragments were visualized by hybridization to two minisatellite probes, M13 and pV47-2. Ten restriction endonucleases were tested to determine which gave the most variable fingerprints, and the restriction endonuclease Hinf I was chosen for the study.

To determine the effectiveness of DNA fingerprinting in paternity ascertainment, two cases were examined. In a control test, the paternity of one calf of known parentage was verified by fingerprinting the calf, its dam, and two adult males, one of which was the true sire. In a test case, one calf of unknown paternity was fingerprinted, along with its dam and one of two potential sires. Paternity was determined by eliminating maternal fragments and matching remaining paternal fragments to the correct sire. To determine the effectiveness of DNA fingerprinting for the establishment of relatedness, the proportion of fragment sharing was determined between all possible pairs of elephants. Pairs were categorized by their degree of relatedness and divided into three groups: first degree relatives, second and third degree relatives, and unrelated animals. A Kruskal-Wallis one-way analysis of variance was used to look for statistical differences between groups, and individual scores were plotted on distribution graphs to determine the effective range of each probe.

The mean number of fragments scored in Asian elephant fingerprints was $8.0( \pm .40)$ using M13 and $8.2( \pm .34)$ using pV47-2. The DNA fingerprints of Asian elephants were variable enough to effectively verify paternity in the control test. Paternity could not be determined in the 
unknown paternity case where one of the potential sires was unavailable. In this test case, two unique fragments were found in the calf which could not be traced to the dam or the potential sire which was examined. It was not known if these unique fragments indicated paternity exclusion or were the result of mutation. The possibility of partially reconstructing the DNA fingerprint of the unavailable male from his known calves and their dams is discussed.

The mean proportion of fragment sharing between DNA fingerprints of first degree relatives, second and third degree relatives, and unrelated animals was $0.62( \pm .04), 0.46( \pm .03)$, and $0.26( \pm .01)$, respectively, using M13, and 0.65 ( \pm .06$), 0.54( \pm .06)$, and $0.30( \pm .01)$ for pV47-2. Variability was relatively high compared to other species reported. Significant differences were found between unrelated animals and first degree relatives using both probes, and between unrelated animals and second and third degree relatives for M13 only. The distribution graphs of individual scores indicated a large area of overlap for all relatedness categories with both probes, although this area was smaller with probe M13. M13 was thus determined to be the most effective of the two probes for establishing degrees of relatedness, with animals sharing less than 0.35 of their fragments being unrelated, and animals sharing greater than 0.62 of their fragments being first degree relatives.

DNA fingerprinting is an effective tool for paternity ascertainment when all potential sires can be tested, and can be used to establish relatedness when the effective range of the probe is known. The discovery of additional probes with higher discriminatory power will further improve the effectiveness of this technique for use on Asian elephants. 


\title{
DNA FINGERPRINTING ANALYSIS OF CAPTIVE ASIAN ELEPHANTS, ELEPHAS MAXIMAS
}

\author{
by \\ LAURA LOUISE BISCHOF
}

A thesis submitted in partial fulfillment of the requirements for the degree of

\section{MASTER OF SCIENCE in BIOLOGY}

Portland State University 1990 
TO THE OFFICE OF GRADUATE STUDIES:

The members of the Committee approve the thesis of Laura Louise Bischof presented January 19, 1990.

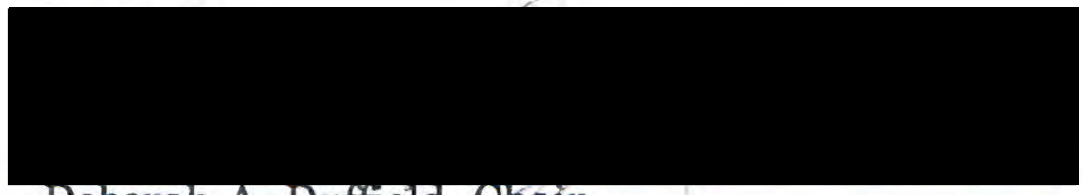

Deborah A. Duffield, Chair

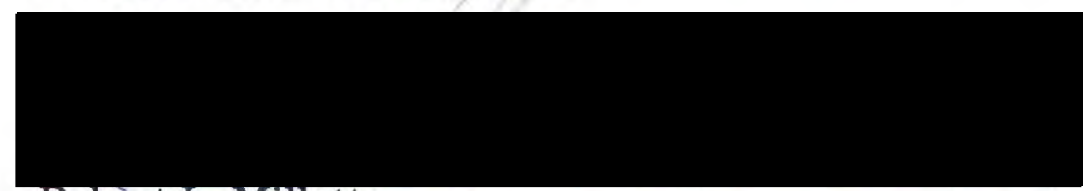

Robèrt L. Millette

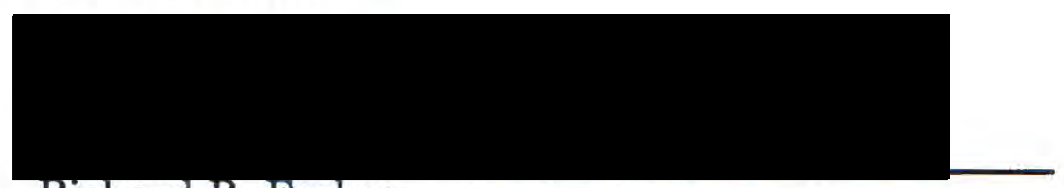

Richard B. Forbes

Sandra S. Snyder

APPROVED:

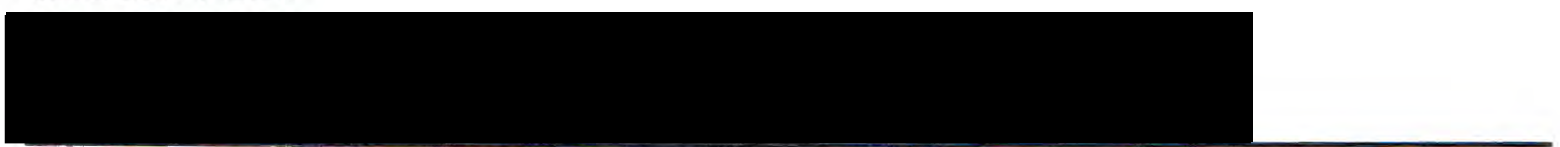

W. Herman Taylor, Chair, Department of Biology

C.William Savery, Interim Vice Provost for Graduate Studies and Research 


\section{ACKNOWLEDGEMENTS}

I will be forever indebted to my advisor and friend, Dr. Deborah Duffield, without whose enthusiasm, support, and advice this study would not have been possible. My love to my parents and all of my friends for emotional support and for feeding me when money was lacking. Special thanks to Dr. J. L. Longmire for providing the pV47-2 probe, and to the following people for technical assistance: Dr. Michael Schmidt, Dr. Bob Sheehy, Dr. Jill Mellen, Tracy Stevens, and Mike Keele. I would also like to thank the following zoological parks for providing blood samples: Washington Park Zoo in Portland, Oregon; Busch Gardens in Tampa, Florida; and Marine World Africa USA in Vallejo, California. This study was funded in part by a Nixon Griffis Fund for Zoological Research grant. 


\section{TABLE OF CONTENTS}

PAGE

ACKNOWLEDGEMENTS ........................................................ ii

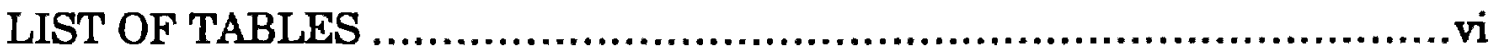

LIST OF FIGURES .............................................................

INTRODUCTION

Asian Elephants............................................................

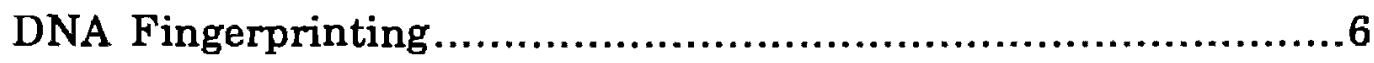

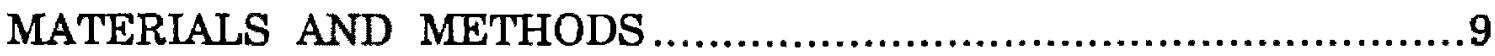

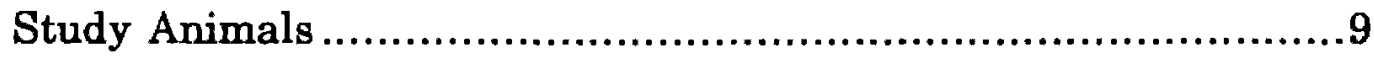

Blood Sampling and DNA Extraction.................................... 12

Sample Restriction and Gel Electrophoresis ........................... 12

Preparation of Radiolabelled Probes..................................... 15

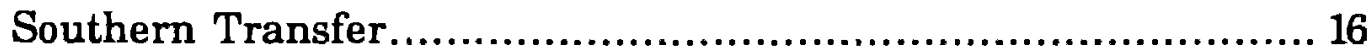

Analysis of DNA Fingerprints ........................................... 16

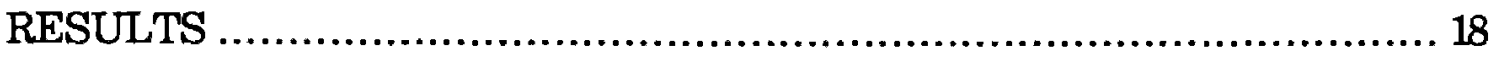

DNA Fingerprinting of Asian Elephants Using M13.................. 19

Suitability of Restriction Enzymes................................... 18

Verification of Paternity in a Known Mating Using M13 .... 18

Paternity Determination of a Test Case Using M13............ 24

Fragment Sharing Using M13 ................................ 24 
DNA Fingerprinting of Asian Elephants Using pV47-2 ...........28

Verification of Paternity in a Known Mating Using pV47-2 ...................................................... 28

Paternity Determination of a Test Case Using pV47-2 ....... 31

Fragment Sharing Using pV47-2.............................. 31

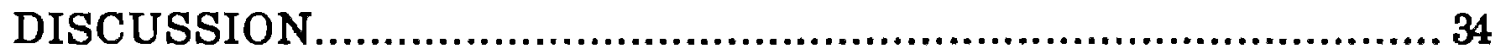

DNA Fingerprinting in Asian Elephants ........................... 34

Paternity Determination in Asian Elephants by DNA

Fingerprinting.................................................. 37

Estimation of Relatedness by DNA Fingerprinting .................39

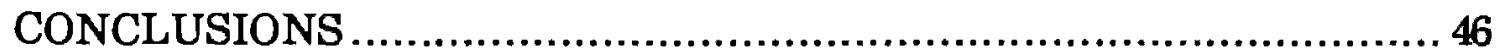

REFERENCES............................................................... 47

APPENDICES

A TOTAL DNA EXTRACTION FROM WHOLE BLOOD ....... 51

B MODIFIED SOUTHERN BLOT PROCEDURE FOR DNA FINGERPRINTING ............................ 53

C RADIOLABELLING OF PROBES............................ 55

D TRICHLOROACETIC ACID PRECIPITATION OF NUCLEIC ACIDS. 


\section{LIST OF TABLES}

TABLE

PAGE

I Asian Elephants Used in This Study Listed By

Name, Sex, Date of Birth, Origin, Dam

and Sire, and Current Location....................... 10

II Related Pairs of Asian Elephants Used in This Study

and Their Degrees of Relatedness

13

III Recognition Sequences of Restriction Endonucleases

Utilized in the Study. 14

IV Mean Number of Fragments Scored and Mean

Proportion of Fragments Shared for Asian

Elephants Using Ten Restriction Enzymes and

an M13 Hypervariable Probe 19

V Fragment Sharing Proportions for Asian Elephants Used in This Study Using M13 Compared Across

Film One 25

V I Fragment Sharing Proportions for Asian Elephants Used in This Study Using M13 Compared Across

Film Two 27

VII Mean Proportion of Fragments Shared for All

Relatedness Categories Using M13 and pV47-2 28 
VIII Fragment Sharing Proportions for Asian Elephants

Used in This Study Using pV47-2 Compared

Across Film One

IX Fragment Sharing Proportions for Asian Elephants

Used in This Study Using pV47-2 Compared

Across Film Two 33

X Summary of Data Reported on Mean Number of

Fragments Scored and Mean Proportion of

Fragments Shared for 13 Species With Six

Different Hypervariable Probes. 35 


\section{LIST OF FIGURES}

FIGURE

PAGE

1. Distribution of Asian Elephants (Elephas maximas)............3

2. Pedigrees of Related Elephants Used in This Study........... 11

3. DNA Fingerprints of Asian Elephants Using the

Restriction Enzymes Pvu II, Msp I, BamH I, and Bgl II.................................................. 20

4. DNA Fingerprints of Asian Elephants Using the

Restriction Enzymes Hae III, Alu I, and

Hinf I

5. DNA Fingerprints of Asian Elephants Using the

Restriction Enzymes Rsa I, Mbo I, and Sau96 I

6. Verification of Paternity in a Known Mating

Using M13 .............................................. 28

7. Paternity Determination of a Test Case Using M13 ...........26

8. Verification of Paternity in a Known Mating

Using pV47-2

9. Paternity Determination of a Test Case Using $\mathrm{pV} 47-2$ 
10. Partial Reconstruction of the DNA Fingerprint of a Deceased Male By Examination of His Calves and Their Dams.

11. Distribution of Fragment Sharing Scores for Pairs of Elephants of Varying Degrees of Relatedness Using pV47-2 42

12. Distribution of Fragment Sharing Scores for Pairs of Elephants of Varying Degrees of Relatedness Using M13 44 


\section{INTRODUCTION}

Zoological parks play an increasingly important role in the conservation and propagation of endangered species. As wild populations dwindle, there is a continuing emphasis on creating self-sustaining populations in zoos. One important element in attaining this goal is genetic management. A frequently cited objective in the genetic management of captive propagation programs is the prevention of inbreeding and subsequent loss of genetic variability (Flesness 1977; Foose 1983; Ralls \& Ballou 1983). This thesis looks at the genetic management of one endangered species in captivity, the Asian elephant (Elephas maximas, Linnaeus 1758).

Captive-bred populations are often characterized by low founder numbers, unequal founder contributions and low reproductive rates (Bouman 1977; Flesness 1977; Ralls et al. 1980; Templeton \& Read 1983). Species which are not adapted to inbreeding in the wild often suffer from inbreeding depression in captivity (Bouman 1977; Ralls et al. 1980; Templeton \& Read 1984;). Effects of inbreeding depression include decreased viability and fecundity, low birth weights, and increased juvenile mortality in laboratory (Wright 1977), domestic (Lasley 1978) and zoo animals (Bouman 1977; Ralls et al. 1979; Ralls et al. 1980; Ralls and Ballou 1982a, b). Inbreeding depression has been documented in captive populations of several species including Speke's gazelle (Gazella spekei), Dorcas gazelle (Gazella dorcas), and Przewalski's horse (Equus 
przewalski) (Bouman 1977; Ralls et al. 1980; Templeton \& Read 1984). Juvenile mortality was found to be higher in inbred compared to outbred matings of 15 out of 16 primate species and in 15 out of 16 ungulate species

examined (Ralls et al. 1979; Ralls \& Ballou 1982a, b). In Asian elephants, $66 \%$ of inbred matings resulted in juvenile mortality, whereas only $15 \%$ of non-inbred offspring died as juveniles (Ralls et al. 1979). The avoidance of inbreeding is now considered an important element of Asian elephant propagation programs (American Association of Zoological Parks and Aquariums, 1989).

\section{ASIAN ELEPHANTS}

Asian elephants belong to the family Elephantidae in the order Proboscidea. Asian elephants (Elephas maximas) have been divided into four subspecies: Indian (Elephas maximas bengalensis), Ceylon (Elephas maximas maximas), Sumatran (Elephas maximas sumatrana), and Malaysian (Elephas maximas hirsutus) (Olivier 1978). There are currently estimated to be 35,000 to 40,000 Asian elephants in the wild in pockets throughout Asia and Sri Lanka (Figure 1). These populations are continually being fragmented and decreased in number due to habitat loss and poaching (Olivier 1978; Dobias 1987; Lumpkin \& Seidensticker 1987). Although Asian elephants have been kept in captivity for hundreds of years, breeding programs for ceremonial and work elephants in Asia are rare (Seidensticker 1984). Asian elephants have been listed as an endangered species since 1975 and have been on Appendix I of CITES since 


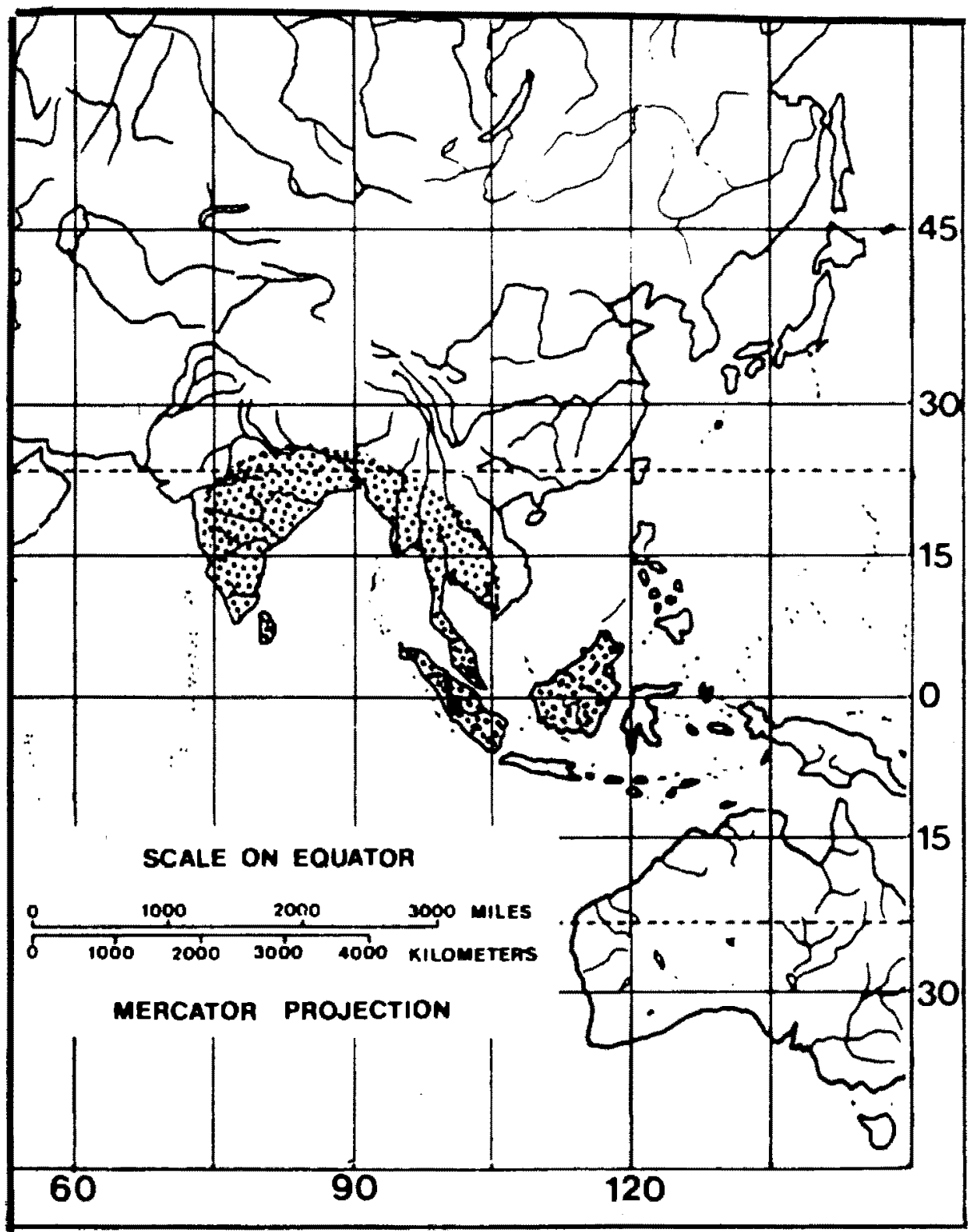

Figure 1. Distribution of Asian elephants (Elephas maximas). From Orders and Families of Recent Mammals of the World, Anderson, S., \& Jones, J. K., Jr., eds., John Wiley \& Sons, New York, U.S.A. 1984. 
1976. Given the concern for dwindling wild populations, the American Association of Zoological Parks and Aquariums (AAZPA) instituted an Asian elephant Species Survival Plan (SSP) in 1985. This program is dedicated to preserving the demographic and genetic integrity of the captive Asian elephant population through cooperative and scientific management. There are presently 150 Asian elephants in 51 SSP participating institutions in North America.

Asian elephants have historically bred poorly in captivity. Several factors contribute to this. Elephants as a species have a very low reproductive rate and do not reach sexual maturity until approximately ten years of age. The gestation period is 22 months, cows generally give birth to only one calf per pregnancy, and the interbirth interval is approximately four years (Maberry 1962; Kurt 1970). Given that the reproductive span for females appears to be approximately 30 years, one cow could be expected to produce a maximum of eight calves in her lifetime (Kurt 1974). In addition, many zoos are not equipped to house bull elephants because of their aggressive and unpredictable nature. Male Asian elephants periodically undergo a physiological condition called musth. This state is characterized by heightened levels of testosterone, physical symptoms such as temporal gland secretions, dribbling of urine, and unpredictable, highly aggressive behavior. Males in musth often attack and attempt to kill their trainers (Alexander 1983; Henneous et al. 1987). Several bulls have been destroyed after killing trainers during musth. The majority of zoos do not have the special facilities to house such animals. Of the 150 Asian elephants currently held in North American SSP participating zoos only 23 are bulls. 
Fifty-four births have occurred in the total North American captive population of Asian elephants in the last one-hundred years (Rapaport, personal communication). Although these calves were sired by perhaps 15 males, $50 \%$ of them were sired by one bull and his offspring. Forty-two percent were born to six females (including two mother-daughter pairs). Four calves are currently listed in the SSP studbook as having unknown sires (Keele 1989). A recent demographic study found that the present captive Asian elephant population in North America is declining at a rate of $15 \%$ per year (Rapaport, personal communication). Accordingly, breeding efforts are being intensified. The current breeding population is producing an average of six calves per year, yet the most recent Asian elephant SSP masterplan cites a goal of ten to 12 births per year. This will require a minimum of 20 to 25 attempted matings per year. Due to the small number of successfully breeding animals and their unequal genetic contribution to date, the genetic relatedness of all animals will be an important factor when planning these captive matings. Effective methods are currently being sought to establish the paternity and genetic relatedness of all potential breeding elephants.

Genetic methods of paternity testing such as chromosome heteromorphism analysis and protein electrophoresis have been found to be ineffective for Asian elephants because of low levels of variability (Duffield et al., unpublished data; Lawson, personal communication). However, DNA fingerprinting has become a powerful tool in paternity testing in humans and other species because of the high variability it detects. Developed by Dr. Alec Jeffreys in 1985, this technique has been used 
successfully for paternity determination and estimates of genetic relatedness in a number of mammalian species (Burke \& Bruford 1987; Jeffreys et al. 1987; Wetton et al. 1987; Georges et al. 1988a, b; Weiss et al. 1988).

\section{DNA FINGERPRINTING}

Hypervariable minisatellite regions consist of variable length tandem repeats of short nuclear DNA sequences. The first hypervariable minisatellite region was identified in human DNA by Wyman and White in 1980. Other hypervariable regions were soon discovered (Bell et al. 1982; Proudfoot et al. 1982; Goodbourn et al. 1983; Jarman et al. 1986). Jeffreys et al. (1985a) described a group of human minisatellite regions near the human myoglobin gene containing repeats of a 33 bp unit which varied in length from 14 to over 500 repeats. Each unit contained the $16 \mathrm{bp}$ conserved "core" sequence, 5' GGAGGTGGGCAGGARG 3' (Jeffreys et al. 1985b).

It was discovered that when flanking DNA was removed by cleavage with restriction endonucleases and the DNA was electrophoresed through an agarose gel, core-specific probes could be used to detect multiple minisatellite fragments simultaneously by Southern blotting procedures (Jeffreys et al. 1985a). These regions appear as "fingerprints," or multiple bands on an autoradiograph. An average of 15 fragments can be detected in human DNA using Jeffreys' probe 33.15. DNA fingerprints produced by this probe have been found to be so variable that the chance of two unrelated humans having identical patterns has been estimated at less than $3 \times 10^{-11}$. DNA fingerprint fragments are somatically stable and are inherited 
(Jeffreys et al. $1985 \mathrm{a}, \mathrm{b}$ ). All fragments in an offspring are traceable to either parent. Thus, by eliminating fragments originating, or potentially originating, from the mother, remaining "obligate" paternal fragments can be used to ascertain paternity among several possible fathers. This technique has been successfully used to determine paternity in humans, dogs, birds, horses, pigs, and primates (Jeffreys et al. 1985a, b; Burke \& Bruford 1987; Wetton et al. 1987; Dixson et al. 1988; Georges et al. 1988a, b; Weiss et al. 1988). Unique fragments occasionally found in the offspring which are not traceable to either parent are thought to be the result of mutation (Jeffreys et al. 1985 a, b; Jeffreys et al. 1988).

Several minisatellite probes are now in use. In addition to Jeffreys' two original probes, 33.15 and 33.6, the wild type bacteriophage M13 has been found to produce DNA fingerprints in both human and animal species (Vassart et al. 1987; Georges et al. 1988a). The pV47-2 probe was developed by J. L. Longmire (Los Alamos, New Mexico) by probing a human genomic library with M13. Numerous additional probes are in use and new probes are being continually developed. All probes which have been reported to date appear to detect different minisatellite regions.

In addition to the use of DNA fingerprinting for paternity analysis, there is also an interest in using this technique more broadly in field studies for the determination of genetic relatedness when pedigrees are unknown. Because of the heritability of minisatellite fragments, the proportion of fragment sharing between fingerprints of individuals may be an indicator of their relatedness. First degree relatives (parent-offspring) should share $50 \%$ of their fragments, while second degree relatives (half- 
siblings, grandparent-offspring) should share 25\%, and so on (Wetton et al. 1987). These expected values have been found to correspond to actual fragment sharing values among wild house sparrows (Passer domesticus) of known relatedness (Wetton et al. 1987). It has been hypothesized that wild African elephants associating in small cohesive family groups are related (Douglas-Hamilton 1975; Moss 1988). It is not known if wild Asian elephants share a similar social structure. Evaluating the proportion of fragment sharing within and between groups of these elephants could possibly be used to help elucidate the social structure of Asian elephants in the wild.

I undertook this study to test the applicability of DNA fingerprinting for paternity and relatedness determination in Asian elephants. I conducted DNA fingerprinting studies on a group of captive Asian elephants of known relatedness from three North American zoos. I examined the effectiveness of DNA fingerprinting for ascertaining paternity by verifying the sire of one calf of known paternity and attempting to determine the sire of one calf of uncertain paternity. To assess the effectiveness of this technique for the determination of relatedness, I compared the proportion of fragments shared between elephants of different degrees of known relatedness. I then ascertained whether or not this technique would have accurately predicted the degree of relatedness of these elephants had their true relationships been completely unknown. 


\section{MATERIALS AND METHODS}

\section{STUDY ANIMALS}

Blood samples were obtained from 18 captive Asian elephants from three North Americn zoos: Washington Park Zoo (WPZ) in Portland, Oregon; Marine World Africa USA (MWA) in Vallejo, California; and Busch Gardens (BG) in Tampa, Florida (Table I). The elephants ranged in age from six to 40 . Thirteen animals were wild caught and are presumed to be unrelated. Pedigrees of animals known to be related are illustrated in Figure 2.

To determine the effectivenss of DNA fingerprinting for paternity determination, two cases were examined. In a control test, the paternity of one calf of known parentage was verified. This was done by fingerprinting the dam, calf, and two adult males, one of which was the true sire. In a test case, one calf of unknown paternity was fingerprinted along with its dam and one of two potential sires. The second potential sire was unavailable for sampling.

In order to determine if DNA fingerprinting could be used to determine relatedness, every possible pairwise combination of elephants was categorized as either unrelated, first degree related, second degree or third degree related. Parents and offspring were categorized as first degree relatives. Half-siblings and grandparent-offspring pairs were categorized as second degree relatives. In two instances the sire of one animal was the grandsire of another. This is a third degree relationship, but was combined 
TABLE I

ASIAN ELEPHANTS USED IN THIS STUDY LISTED BY NAME, SEX, DATE OF BIRTH, ORIGNN, DAM AND SIRE, AND CURRENT LOCATION

\begin{tabular}{|c|c|c|c|c|c|c|}
\hline NAME & SEX & $\begin{array}{c}\text { DATE } \\
\text { OF } \\
\text { BIRTH } \\
\end{array}$ & ORIGIN & DAM & SIRE & $\begin{array}{l}\text { CURRENT } \\
\text { LOCATION } \\
\end{array}$ \\
\hline Belle & $\mathbf{F}$ & Ca. 1952 & Thailand & Wild & Wild & WPZ \\
\hline Birka & $\mathbf{F}$ & Ca. 1967 & Unknown & Wild & Wild & $\mathrm{BG}$ \\
\hline Jenney & $\mathbf{F}$ & 1940 & Unknown & Wild & Wild & MWA \\
\hline Hanako & $\mathbf{F}$ & $\mathrm{Ca} .1963$ & Portland, OR & Tuy Hoa & Thonglaw & WPZ \\
\hline Hugo & $\mathbf{M}$ & Ca. 1960 & Unknown & Wild & Wild & WPZ \\
\hline Josky & $\mathbf{F}$ & 1967 & Unknown & Wild & Wild & $\mathrm{BG}$ \\
\hline Judy & $\mathbf{F}$ & 1966 & Thailand & Wild & Wild & MWA \\
\hline Mala & $\mathbf{F}$ & Ca. 1966 & Unknown & Wild & Wild & BG \\
\hline MeTu & $\mathbf{F}$ & 1962 & Portland, OR & Rose & Thonglaw & WPZ \\
\hline Packy & $\mathbf{M}$ & 1962 & Portland, OR & Belle & Thonglaw & WPZ \\
\hline Pet & $\mathbf{F}$ & Ca. 1955 & Thailand & Wild & Wild & WPZ \\
\hline Roman & $\mathbf{M}$ & 1983 & Orlando, FL & Sid & $\begin{array}{l}\text { Hugo/ } \\
\text { Vance }\end{array}$ & MWA \\
\hline Rose & $\mathbf{F}$ & Ca. 1949 & Thailand & Wild & Wild & WPZ \\
\hline Sid & $\mathbf{F}$ & Ca. 1964 & Unknown & Wild & Wild & $\mathrm{BG}$ \\
\hline Sung Surin & $\mathbf{F}$ & 1982 & Portland, OR & Pet & Packy & WPZ \\
\hline Tadji & $\mathbf{F}$ & 1943 & Unknown & Wild & Wild & M WA \\
\hline Tamba & $\mathbf{F}$ & 1971 & Thailand & Wild & Wild & WPZ \\
\hline Tina & $\mathbf{F}$ & 1957 & Unknown & Wild & Wild & MWA \\
\hline
\end{tabular}

WPZ = Washington Park Zoo, Portland, OR.

BG = Busch Gardens, Tampa, FL.

MWA = Marine World Africa USA, Vallejo, CA. 
for this comparison with second degree relatives because of low sample size. First, second, and third degree related pairs are listed in Table II.

\section{BLOOD SAMPLING AND DNA EXTRACTION}

Blood samples were taken from the ear vein of the elephants as part of normal husbandry procedures at the Wasington Park Zoo in Portland, Oregon. Samples were taken at other institutions upon request. Approximately $10 \mathrm{ml}$ of blood were taken and placed in heparinized Vacutainer tubes and shipped on ice to Portland State University within two days of drawing. Total cellular DNA was extracted from white blood cells within 72 hours of arrival using the procedure cited in Appendix A. DNA yields varied from 100 to $500 \mu \mathrm{g}$ and were stored at concentrations of $1-4 \mu \mathrm{g} / \mu \mathrm{l}$ in TE buffer (10 mM Tris- $\mathrm{HCl} \mathrm{pH} 8.0,1 \mathrm{mM}$ EDTA pH 8.0) at $4^{\circ} \mathrm{C}$.

\section{SAMPLE RESTRICTION AND GEL ELECTROPHORESIS}

Ten different restriction enzymes (Table III) were tested to determine which enzyme would produce the greatest number of variable fragments. DNA fingerprints of four animals (three related and one unrelated) were compared using all ten enzymes. Ten $\mu \mathrm{g}$ of DNA were restricted with 20 units of enzyme for each animal. The reaction buffer supplied with each enzyme was added to a concentration of $1 / 10$ the calculated total reaction volume. Sterile water was added to keep the buffer and enzyme concentration at $1 / 10$ the total reaction volume. Restriction mixtures were placed in a $37^{\circ} \mathrm{C}$ water bath for $2-5$ hours, depending upon the reactivity of each enzyme. One-tenth volume of $10 \mathrm{X}$ tracking dye $(50 \% \mathrm{w} / \mathrm{v}$ sucrose, $0.2 \mathrm{M}$ EDTA ph $8.0,0.25 \% \mathrm{w} / \mathrm{v}$ bromophenol blue, $0.25 \% \mathrm{w} / \mathrm{v}$ xylene cyanol) 
TABLE II

RELATED PAIRS OF ASIAN ELEPHANTS USED IN THIS STUDY AND THEIR DEGREES OF RELATEDNESS

\begin{tabular}{|c|c|c|c|}
\hline NAME & $\begin{array}{l}\text { COMMON } \\
\text { RELATIVE } \\
\end{array}$ & $\begin{array}{l}\text { TYPE OF } \\
\text { RELATIONSHIP }\end{array}$ & $\begin{array}{l}\text { DEGREE OF } \\
\text { RELATEDNESS }\end{array}$ \\
\hline Rose + MeTu & & Dam-Calf & 1st \\
\hline Bell + Packy & & dam-calf & 1st \\
\hline Packy + Sung Surin & & sire-calf & 1st \\
\hline Pet + Sung Surin & & dam-calf & 1st \\
\hline Sid + Roman & & dam-calf & 1st \\
\hline MeTu + Hanako & Thonglaw & half-siblings & 2nd \\
\hline $\mathrm{MeTu}+$ Packy & Thonglaw & half-siblings & 2nd \\
\hline Hanako + Packy & Thonglaw & half-siblings & 2nd \\
\hline Belle + Sung Surin & Belle & granddam-grandcalf & 2nd \\
\hline MeTu + Sung Surin & Thonglaw & $\begin{array}{l}\text { Thonglaw is sire of } \\
\text { MeTu and grandsire } \\
\text { of Sung Surin }\end{array}$ & 3rd \\
\hline $\begin{array}{l}\text { Hanako + Sung } \\
\text { Surin }\end{array}$ & Thonglaw & $\begin{array}{l}\text { Thonglaw is sire of } \\
\text { Hanako and } \\
\text { grandsire of } \\
\text { Sung Surin }\end{array}$ & $3 r d$ \\
\hline
\end{tabular}

was added to stop the reaction. The binding of cohesive ends was prevented by placing the samples at $65^{\circ} \mathrm{C}$ for three minutes. Samples were cooled on ice prior to loading into the gel.

Samples were run in a $22 \mathrm{~cm}$ long horizontal gel apparatus using a $1 \mathrm{~cm}$ thick $0.7 \%$ or $0.8 \%$ agarose gel. One lane on each gel was loaded with $0.5 \mu \mathrm{g}$ of $\lambda /$ Hind III size marker. Size markers were also placed at $65^{\circ} \mathrm{C}$ for 
TABLE III

RECOGNITION SEQUENCES OF RESTRICTION

ENDONUCLEASES UTLIZED IN THE STUDY

ENZYME

RECOGNITION SEQUENCE

\section{SIX BASE PAIRS}

BamH I

Bgl II

Pvu II

Hinf I

Sau96 I

Alu I

Hae III

Mbo I

Msp I

Rsa I
$\mathrm{G} \downarrow \mathrm{GATCC}$

A $\downarrow$ GATCT

CAT $\downarrow$ CTG

FIVE BASE PAIRS

G $\downarrow$ ANTC

$\mathrm{G} \downarrow \mathrm{GNCC}$

FOUR BASE PAIRS

$\mathrm{AG} \downarrow \mathrm{CT}$

$\mathrm{GG} \downarrow \mathrm{CC}$

$\mathrm{C} \downarrow \mathrm{CGG}$

$\downarrow$ GATC

$\mathrm{GT} \downarrow \mathrm{AC}$

three minutes prior to loading to prevent the binding of cohesive ends. Gels were run under Tris borate buffer $(0.089 \mathrm{M}$ Tris base, $0.089 \mathrm{M}$ boric acid, 0.002 M EDTA ph 8.0) at 150 volts for ten minutes followed by 70 volts for 16 hours. 


\section{PREPARATION OF RADIOLABELLED PROBES}

Two different probes were used in this study, M13 and pV47-2. M13 is a bacteriophage containing a minisatellite core sequence in its protein III gene. pV47-2 was developed by Dr. J. L. Longmire (Los Alamos, New Mexico) by probing a human genomic library with M13. The pV47-2 probe was kindly provided by Dr. Longmire for this study. Both probes were used in their entirety. Single stranded M13 mp8 DNA was purchased from Sigma Chemical Company (St. Louis, Missouri) and linearized by restriction with BamH I. An end labelling procedure was used to label the probe DNA radioactively. Two hundred nanograms of the single stranded linear M13 DNA were heated to $100^{\circ} \mathrm{C}$ for two minutes to prevent selfbinding and combined with $1 \mu \mathrm{l}$ bovine serum albumen (BSA, $1 \mathrm{mg} / \mathrm{ml}$ ), $1.25 \mu \mathrm{l}$ primer, and $10 \mu \mathrm{l}$ of a $2.5 \mathrm{X}$ reaction buffer containing dGTP, dATP, and dTTP. Fifty $\mu \mathrm{Ci}$ of $\alpha^{32}$ PdCTP were added along with $1 \mu$ of the Klenow fragment of DNA polymerase I. The reaction was left at room temperature for three to 12 hours. Unincorporated nucleotides were separated by centrifugation through a Sephadex G-50 column (Appendix C). The amount of $\alpha^{32}$ PdCTP incorporated during end labelling was determined by trichloroacetic acid precipitation as described in Appendix D. Incorporation averaged $60 \%$. The specific activity of the probe in hybridization solution averaged $2.0 \times 10^{7} \mathrm{cpm} / \mathrm{ml}$.

Two hundred ng of the pV47-2 probe was prepared for end labelling by partial digestion with a $20 \mathrm{ng} / \mathrm{ml}$ concentration of DNase I for ten minutes at room temperature followed by ten minutes in a boiling water bath. The process of end labelling was performed as described for M13. 
Specific activity of the radioactively labelled pV47-2 probe was slightly lower than that of the M13, at approximately $2.0 \times 10^{6} \mathrm{cpm} / \mathrm{ml}$ of hybridization solution.

\section{SOUTHERN TRANSFER}

DNA was transferred to $18.5 \times 12.5 \mathrm{~cm}$ nylon membranes (Hybond $\mathrm{N}$, Amersham, Arlington Heights, Mlinois) in a solution of 20X SSC ( 3 M $\mathrm{NaCl}, 0.3 \mathrm{M}$ sodium citrate) for 12 hours. DNA was cross-linked onto the membrane by placing the membrane over UV light for eight minutes. Prehybridization of the membrane was performed in a $60^{\circ} \mathrm{C}$ water shaker bath overnight in a solution of $0.7 \% \mathrm{SDS}, 0.263 \mathrm{M} \mathrm{Na}_{2} \mathrm{HPO}_{4}, 1 \mathrm{mM}$ EDTA $\mathrm{pH} 8.0$, and $1 \%$ BSA ( $1 \mathrm{mg} / \mathrm{ml})$. The same solution (fresh) was used for hybridization except that $200 \mathrm{ng}$ of $\alpha^{32}$ PdCTP radiolabelled probe was added. Hybridization was performed in a $60^{\circ} \mathrm{C}$ water shaker bath for 12-24 hours. Stringency washes consisted of two 15 minute washes in $2 \mathrm{X}$ $\mathrm{SSC} / 0.1 \%$ SDS at room temperature and one at $60^{\circ} \mathrm{C}$. Membranes were autoradiographed with two intensifying screens for $6-48$ hours at $-80^{\circ} \mathrm{C}$. The complete procedure is an adaptation of protocols by Maniatis et al. (1982), Amersham, Southern (1975), and Westneat et al. (1988) and is given in Appendix B.

\section{ANALYSIS OF DNA FINGERPRINTS}

Presence or absence of DNA fragments in each animal was scored by comparing across each autoradiograph. Several intensities of autoradiographs were printed and fragments that were still faint on dark intensity films were not scored. Scorable fragments were totalled for each 
individual and pairwise comparisons were made between all animals on the same autoradiograph. Comparisons were not made across autoradiographs because fragment movement varied slightly from gel to gel. Fragments below $\mathbf{3} \mathbf{~ k b}$ in size were not scored.

Paternity determination was made by first eliminating maternal fragments in the DNA fingerprint of the calf and examining males for matching obligate paternal fragments. All obligate paternal fragments had to be present in a male before it was determined to be the sire. The proportion of fragment sharing was determined for unrelated, first degree, second and third degree relatives using the equation

$$
\frac{2 N_{A B}}{N_{A}+N_{B}}
$$

Where $\mathrm{N}_{\mathrm{A}}$ and $\mathrm{N}_{\mathrm{B}}$ are the number of scored fragments for each individual and $\mathrm{N}_{\mathrm{AB}}$ is the number of fragments shared by both (Wetton et al. 1987). Second and third degree relationships were combined into one category to facilitate statistical analysis. Statistically significant differences between groups were determined by a nonparametric sum of ranks test, the Kruskal-Wallis one-way analysis of variance. 


\section{RESULTS}

\section{DNA FINGERPRINTING OF ASIAN ELEPHANTS USING M13}

\section{Suitability of Restriction Enzymes}

DNA from four elephants was fingerprinted with the M13 probe using ten different restriction enzymes. The mean number of fragments scored and the mean proportion of fragments shared for these animals for these ten enzymes using M13 are shown in Table IV. The six-base cutters, BamH I and Bgl II, were found to be unsuitable due to a low number of resolvable fragments (Figure 3). The six-base cutter Pvu II gave more fragments but low variability between individuals (Figure 3). The four- and five-base cutter enzymes Msp I (Figure 3), Hinf I, Alu I (Figure 4), and Rsa I (Figure 5), varied slightly in variability and total number of bands scored, but were considered equally suitable. The five-base cutter Hinf I was chosen because it is the most commonly used enzyme in DNA fingerprinting studies. The use of this enzyme facilitated comparison of my results with those from studies of other species.

\section{Verification of Paternity in a Known Mating Using M13}

To verify the paternity of a calf from a known mating, DNA from the calf (Sung Surin), its dam (Pet), its known sire (Packy), and an unrelated male (Hugo), were fingerprinted using the enzyme Hinf I (Figure 6). All fragments scored in the calf could be traced either to the dam or to the sire. No unique fragments were present in the offspring. Ten offspring 


\section{TABLE IV}

\section{MEAN NUMBER OF FRAGMENTS SCORED AND MEAN}

PROPORTION OF FRAGMENTS SHARED FOR ASIAN ELEPHANTS USING TEN RESTRICTION ENZYMES AND AN M13 HYPERVARIABLE PROBE

\begin{tabular}{llcc} 
& MEAN \# & MEAN RROPORTION OF ERAGMENTS SHARED \\
ENZYME & FRAGMENTS & RELATED (1ST DEGREE) & UNRELATED \\
\hline
\end{tabular}

BamH I

2.0

.75

.29

Bgl II

5.3

.46

.54

Pvu II

12.5

.86

.60

Hinf I

10.7

.66

.38

Sau96 I

7.7

.64

Alu I

8.7

.68

.26

Hae III

9.7

.71

Mbo I

9.0

.71

.51

Msp I

15.5

.65

Rsa I

8.0

.65 
PVU II MSP | BAMH I BGL II

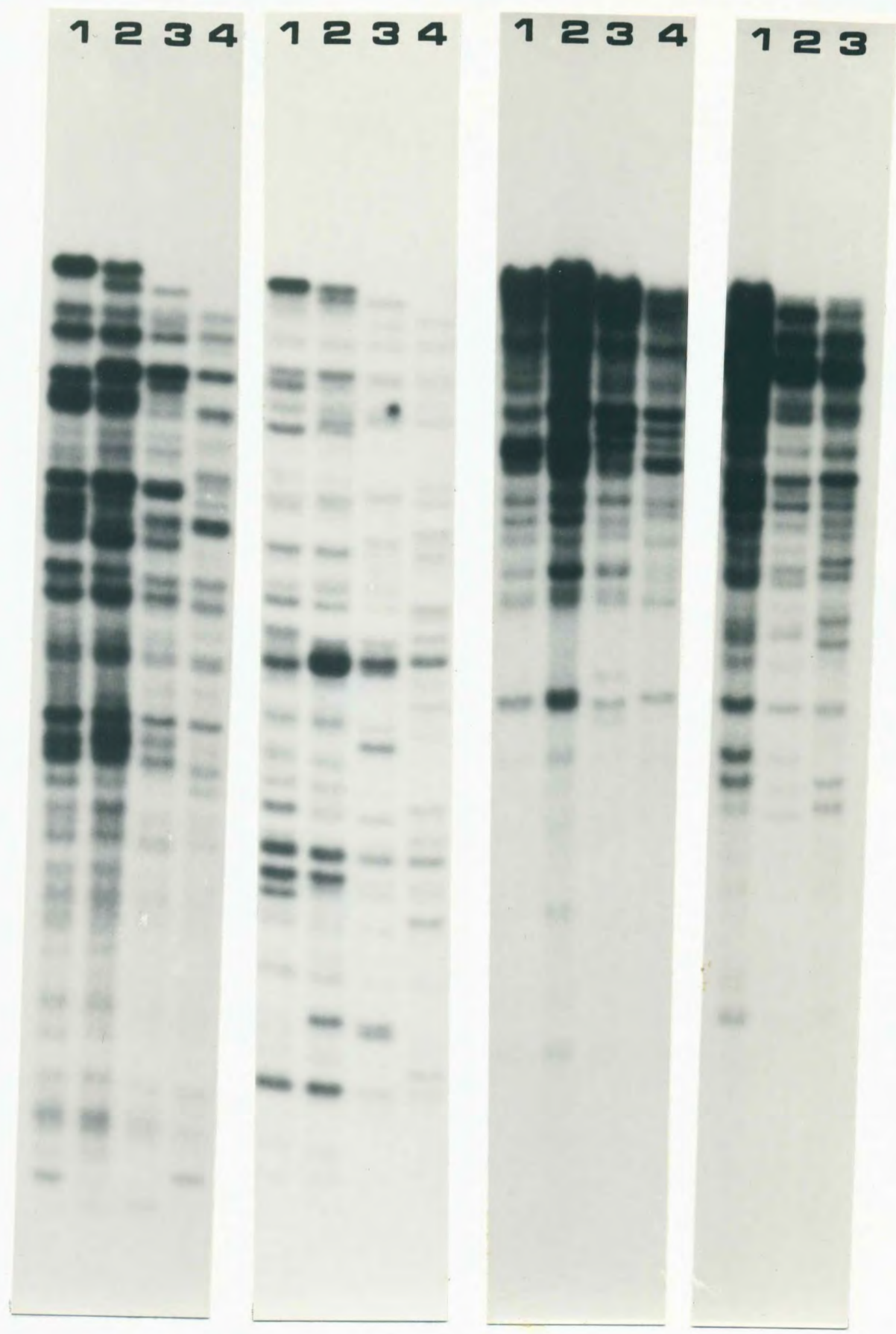

Figure 3. DNA fingerprints of Asian elephants using the restriction enzymes Pvu II, Msp I, BamH I, and Bgl II. Lanes $1,2,3$ and 4 are the fingerprints of four individual animals. 
HAE III

ALU I

HINF I

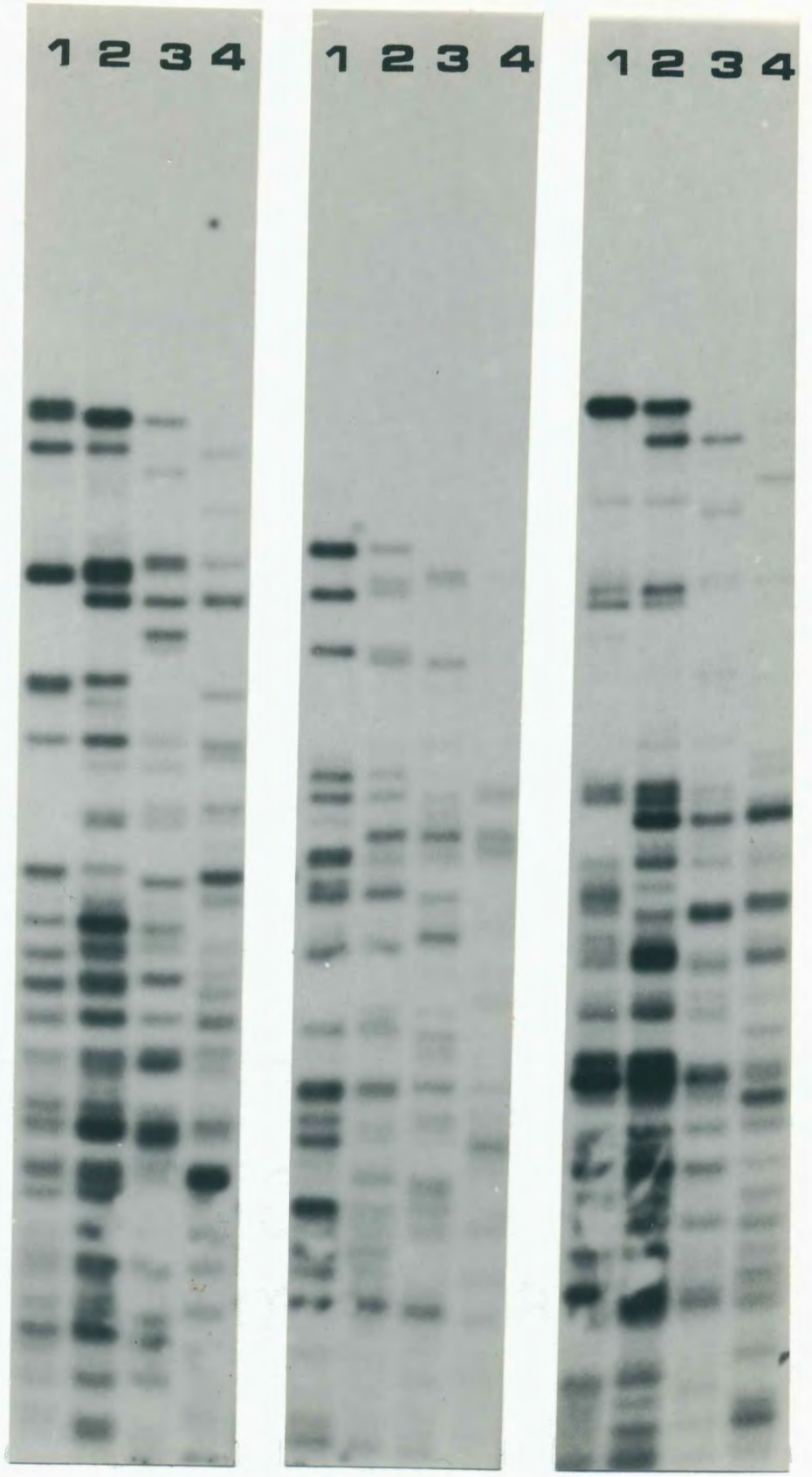

Figure 4. DNA Fingerprints of Asian elephants using the restriction enzymes Hae III, Alu I, and Hinf I. Lanes 1, 2, 3 and 4 are the fingerprints of four individual animals. 


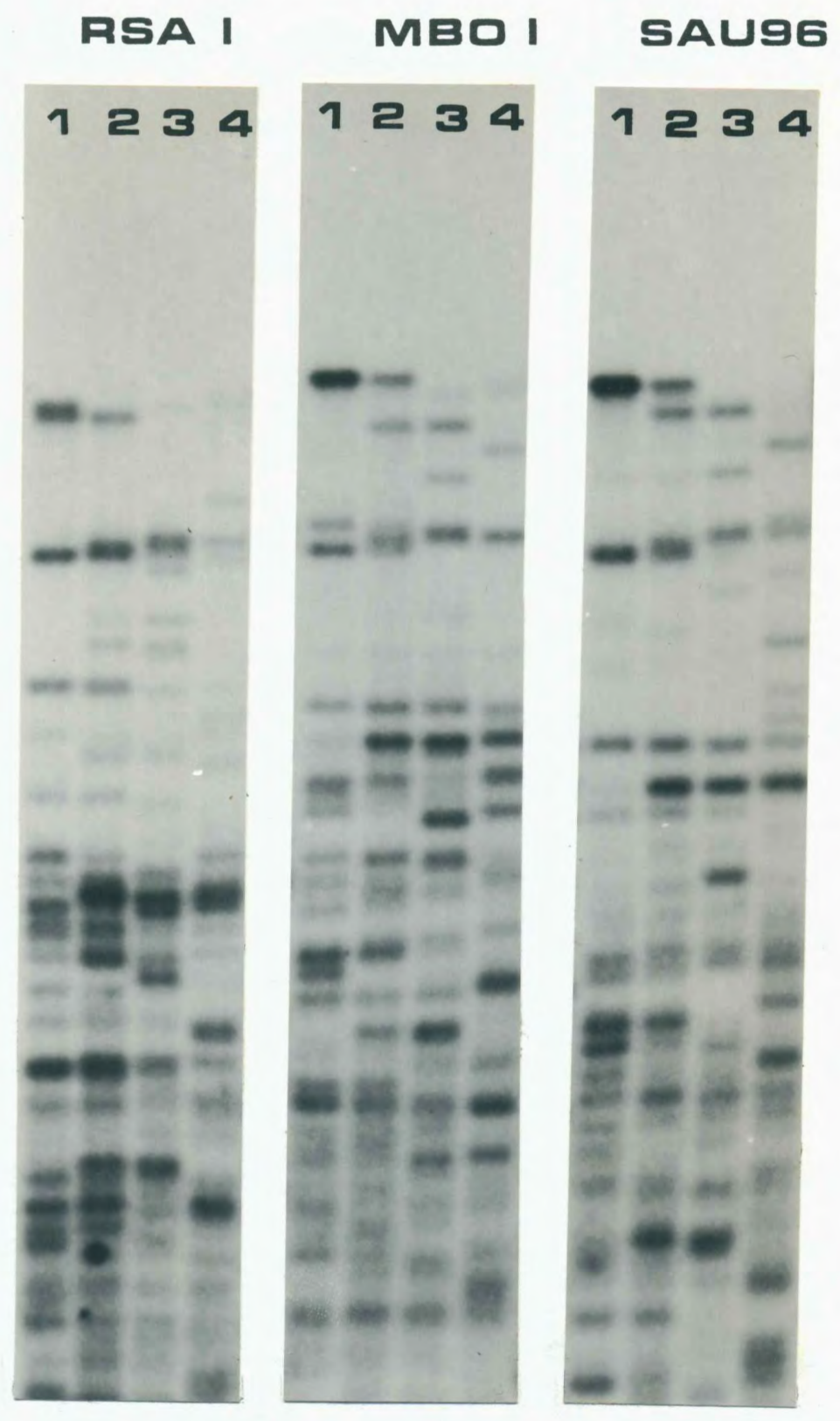

Figure 5. DNA fingerprints of Asian elephants using the restriction enzymes Rsa I, Mbo I, and Sau96 I. Lanes 1, 2, 3 and 4 are the fingerprints of four individual animals. 


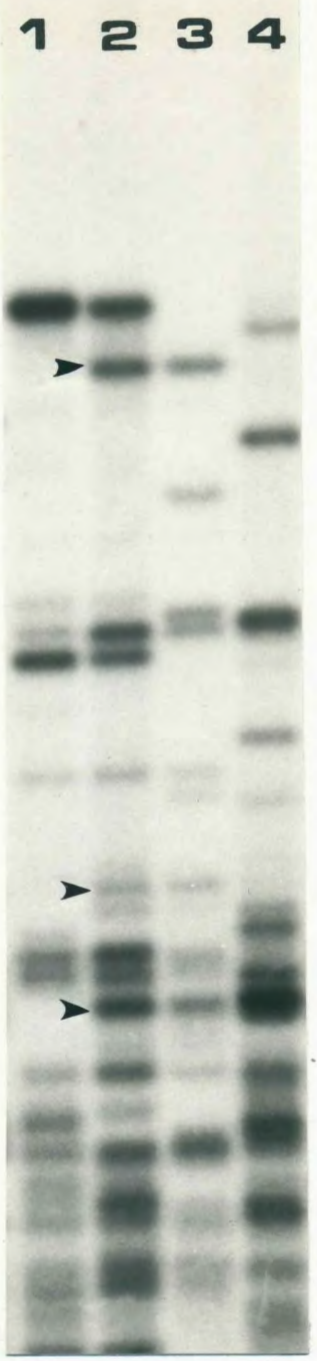

Figure 6 . Verification of paternity in a known mating using M13. Lane 1 is a fingerprint of the dam (Pet), lane 2 is the calf (Sung Surin), lane 3 is the known sire (Packy), and lane 4 is an unrelated male (Hugo). Obligate paternal fragments are indicated by a symbol. 
fragments were scored: four were found in the fingerprint of the dam; three could have come from either the dam or the known sire, and three remaining obligate paternal fragments were found in the fingerprint of the known sire. The unrelated male tested had only one of the three obligate paternal fragments. The proportion of fragment sharing between the offspring and the dam, sire, and unrelated male was $0.78,0.62$, and 0.32 , respectively (5E, 6F, $6 \mathrm{G}$, Table V).

\section{Paternity Determination of a Test Case Using M13}

DNA from one calf of unknown paternity (Roman) was fingerprinted, along with DNA from its dam (Sid) and one potential sire (Hugo) (Figure 7). Eight offspring fragments were scored: four were present in the dam, and there were four obligate paternal fragments. Only one of the two potential sires was available for testing, and he had only three of the four obligate paternal fragments. It is unknown whether the unique fragment in this case excludes that male from paternity or is the result of a spontaneous mutation. The proportion of fragment sharing between the offspring and the dam and potential sire was 0.57 and 0.50 , respectively $(1 \mathrm{~A}, 2 \mathrm{~B}$, Table VI).

Fragment Sharing Using M13

An average of $8.0( \pm .40)$ fragments were scored for every animal using M13. The proportion of fragments shared for all pair-wise combinations of animals is given in Tables V and VI. The mean proportion of fragment sharing between animals was $0.26( \pm .01)$ for unrelated animals and $0.62( \pm .04)$ for first degree relatives. The mean fragment sharing value 
TABLE V

FRAGMENT SHARING PROPORTIONS FOR ASIAN ELEPHANTS USED IN THIS STUDY USING M13 COMPARED ACROSS FILM ONE

\begin{tabular}{lllllllll} 
& A & B & C & D & E & F & G & H \\
\hline & & & & S & & & \\
& & & & u & & & \\
& & & & g & & & \\
& H & & & & & & \\
& a & T & & S & P & & B \\
M & n & a & & u & a & H & e \\
e & a & m & P & r & c & u & l \\
T & k & b & e & i & k & g & l \\
u & o & a & t & n & y & o & e \\
\hline
\end{tabular}

1. Rose

2. $\mathrm{MeTu}$

3. Hanako

4. Tamba

5. Pet

6. Sung Surin

7. Packy

8. Hugo

* = First Degree Relatives

$\Delta=$ Second Degree Relatives

- = Third Degree Relatives
*

$\begin{array}{llllllll}.56 & .21 & .14 & .36 & .32 & .12 & .24 & .21\end{array}$

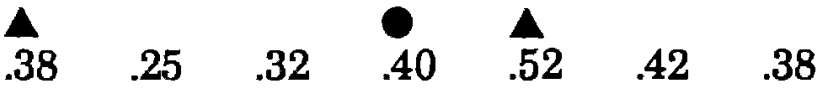

$\begin{array}{llllll}.12 & .42 & .48 & .40 & .20 & .28\end{array}$

$\begin{array}{lllll}.00 & .12 & .14 & .00 & .24\end{array}$

$\begin{array}{llll}* & & & \\ .78 & .34 & .34 & .32\end{array}$

$\begin{array}{lll}* & & \mathbf{A} \\ .62 & .32 & .56\end{array}$

$.44 \quad *$.70 


\section{3}

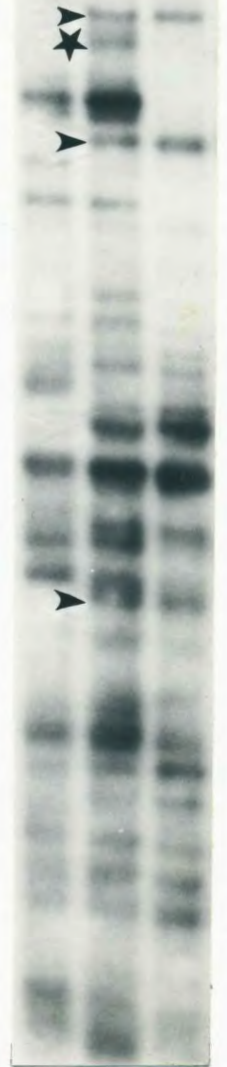

Figure 7. Paternity determination of a test case using M13. Lane 1 is a fingerprint of the dam (Sid), lane 2 is a fingerprint of the calf (Roman), and lane 3 is a fingerprint of one potential sire (Hugo). Obligate paternal fragments are indicated by a - symbol. The unique fragment is indicated by a symbol. 
TABLE VI

FRAGMENT SHARING PROPORTIONS FOR ASIAN ELEPHANTS USED IN THIS STUDY USING M13 COMPARED ACROSS FILM TWO

$\begin{array}{lllllllllllll}\text { A } & \text { B } & \text { C } & \text { D } & \text { E } & \text { F } & \text { G } & \text { H } & \text { I } & \text { J } & \text { K } & \text { L } & \text { M }\end{array}$ $\begin{array}{llllllll}R & P & J & B & \text { e } & \text { T } & \text { T }\end{array}$

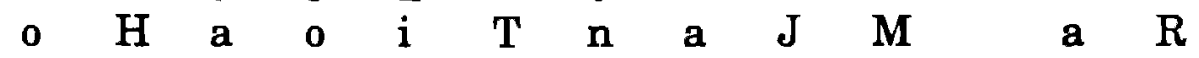
$\begin{array}{lllllllllllll}\mathbf{m} & \mathbf{u} & \mathbf{c} & \mathbf{s} & \mathbf{r} & \mathrm{i} & \mathbf{n} & \mathrm{d} & \mathbf{u} & \mathbf{a} & \mathrm{P} & \mathbf{m} & \mathbf{0}\end{array}$ $\begin{array}{lllllllllllll}\mathbf{a} & \mathbf{g} & \mathbf{k} & \mathbf{k} & \mathbf{k} & \mathbf{n} & \mathrm{e} & \mathbf{j} & \mathbf{d} & \mathbf{l} & \mathrm{e} & \mathbf{b} & \mathbf{s}\end{array}$ $\begin{array}{lllllllllllll}\mathbf{n} & 0 & \mathbf{y} & \mathbf{y} & \mathbf{a} & \mathbf{a} & \mathbf{y} & \mathbf{i} & \mathrm{y} & \mathbf{a} & \mathbf{t} & \mathbf{a} & \mathrm{e}\end{array}$

$\begin{array}{llllllllllllll}\text { 1. Sid } & .57 & .00 & .13 & .00 & .28 & .00 & .31 & .36 & .17 & .31 & .36 & .31 & .00\end{array}$

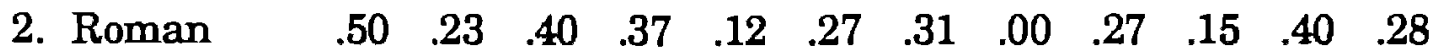

$\begin{array}{llllllllllll}\text { 3. Hugo } & .44 & .54 & .33 & .17 & .36 & .00 & .00 & .00 & .34 & .00 & .24\end{array}$

$\begin{array}{lllllllllll}\text { 4. Packy } & .37 & .35 & .59 & .25 & .28 & .27 & .25 & .34 & .14 & .12\end{array}$

5. Josky $\begin{array}{lllllllll}.53 & .40 & .28 & .33 & .46 & .14 & .00 & .43 & .46\end{array}$

6. Birka $\begin{array}{llllllll}.12 & .40 & .31 & .43 & .40 & .15 & .40 & .40\end{array}$

7. Tina $\begin{array}{lllllll}.27 & .15 & .14 & .53 & .31 & .27 & .14\end{array}$

8. Jenney $\begin{array}{llllll}.33 & .31 & .43 & .17 & .28 & .15\end{array}$

9. Tadji $\begin{array}{lllll}.36 & .17 & .20 & .33 & .00\end{array}$

10. Judy $\begin{array}{llll}.31 & .18 & .31 & .17\end{array}$

11. Mala $\begin{array}{lll}.33 & .43 & .00\end{array}$

12. Pet $.00 \quad .36$

13. Tamba .14

* = First Degree Relatives 
for second and third degree relatives was intermediate at 0.46 ( \pm .03$)$. Mean fragment sharing proportions for all relatedness categories for M13 are summarized in Table VII. A Kruskal-Wallis one-way analysis of variance revealed a significant difference between unrelated animals and first degree relatives $(p<.01)$. The difference between first and second degree relatives was not significant.

\section{TABLE VII}

MEAN PROPORTION OF FRAGMENTS SHARED FOR ALL RELATEDNESS CATEGORIES USING M13 AND pV47-2

RELATEDNESS

CATEGORY

1st Degree Relatives

2nd and 3rd Degree Relatives

Unrelated
MEAN PROPORTION OF FRAGMENTS SHARED $\mathrm{pV} 47-2$ M13

$0.65 \pm .06$

$0.62 \pm .04$

$0.54 \pm .06$

$0.46 \pm .03$

$0.30 \pm .01$

DNA FINGERPRINTING OF ASIAN ELEPHANTS USING pV47-2

Verification of Paternity in a Known Mating Using DV47-2

The calf of a known mating and its dam, sire, and an unrelated male previously fingerprinted with M13 were retested with pV47-2 (Figure 8). Nine bands were scored in the offspring: six of these were found in the fingerprint of the dam, and three obligate paternal fragments were found in the fingerprint of the known sire. The unrelated male tested had two of the three obligate paternal bands. The proportion of fragment sharing between the calf and the dam, sire, and unrelated male was $0.80,0.67$, and 0.23 , respectively (5E, $6 \mathrm{~F}, 6 \mathrm{G}$, Table VIII). 


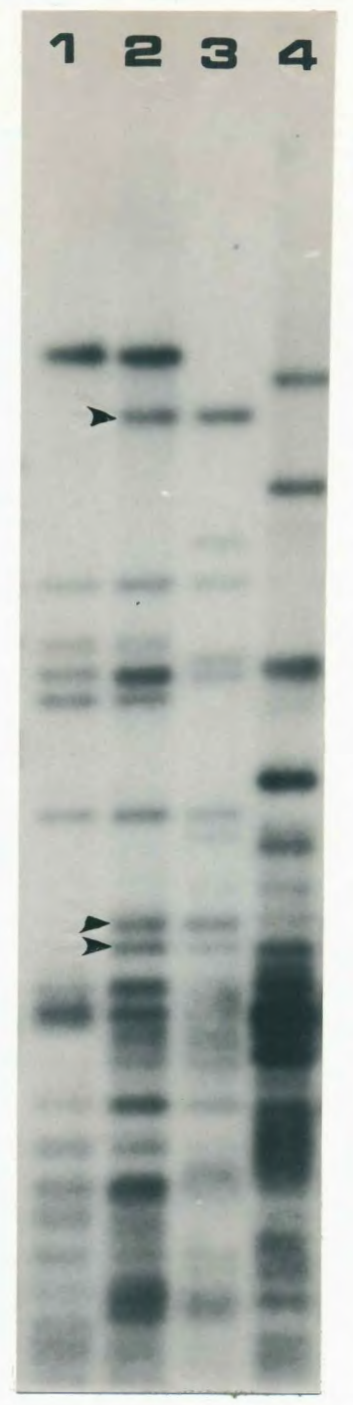

Figure 8 . Verification of paternity in a known mating using pV47-2. Lane 1 is a fingerprint of the dam (Pet), lane 2 is the calf (Sung Surin), lane 3 is the known sire (Packy), and lane 4 is an unrelated male (Hugo). Obligate paternal fragments are indicated by a symbol. 
TABLE VIII

FRAGMENT SHARING PROPORTIONS FOR ASIAN ELEPHANTS USED IN THIS STUDY USING PV47-2 COMPARED ACROSS FILM ONE

\begin{tabular}{lllllllll} 
A & B & C & D & E & F & G & H \\
\hline & & & & S & & & \\
& & & & u & & & \\
& & & & n & & & \\
& H & & & & & & \\
& a & T & & S & P & & B \\
M & n & a & & u & a & H & e \\
e & a & m & P & r & c & u & l \\
T & k & b & e & i & k & g & l \\
u & o & a & t & n & y & o & e
\end{tabular}

1. Rose

2. $\mathrm{MeTu}$

3. Hanako

4. Tamba

5. Pet

6. Sung Surin

7. Packy

8. Hugo

* = First Degree Relatives

$\Delta=$ Second Degree Relatives

- = Third Degree Relatives
*

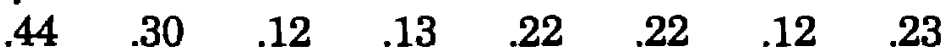

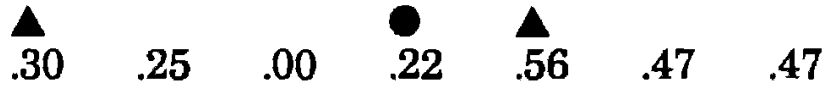

$\begin{array}{llllll}.22 & .47 & .50 & .40 & .32 & .53\end{array}$

$\begin{array}{lllll}.31 & .37 & .25 & .13 & .27\end{array}$

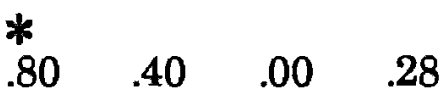

$\begin{array}{lll}* & & \Delta \\ .67 & .23 & .59\end{array}$

$.35 \quad .82$ 


\section{Paternity Determination of a Test Case Using DV47-2}

The calf of unknown paternity and its dam and one potential sire previously fingerprinted with M13 were retested with pV47-2 (Figure 9). Ten offspring fragments were scored: five came from the dam, and four of the five obligate paternal bands were present in the tested male. The offspring had one unique fragment as it did with the M13 probe. The proportion of fragment sharing between the offspring and dam was 0.62 The proportion of fragment sharing between the offspring and the potential sire was 0.53 (1A, 2B, Table IX).

\section{Fragment Sharing Using DV47-2}

The mean number of fragments scored for each animal with $\mathrm{pV47-2}$ was 8.2 ( \pm .34$)$. As with M13, fragments below $3 \mathrm{~kb}$ were not scored. The proportion of fragment sharing for all pair-wise combinations of animals is given in Tables VIII and IX. The mean proportion of fragment sharing was $0.30( \pm .01)$ between unrelated animals, $0.65( \pm .06)$ between first degree relatives, and $0.54( \pm .06)$ between second and third degree relatives. Mean fragment sharing proportions for all relatedness categories for $\mathrm{pV47-2}$ are summarized in Table VII. A Kruskal-Wallis one-way analysis of variance showed a significant difference between unrelated animals and first degree relatives $(p<.01)$. The differences between unrelated animals and second degree relatives and between second degree relatives and first degree relatives were not significant. 


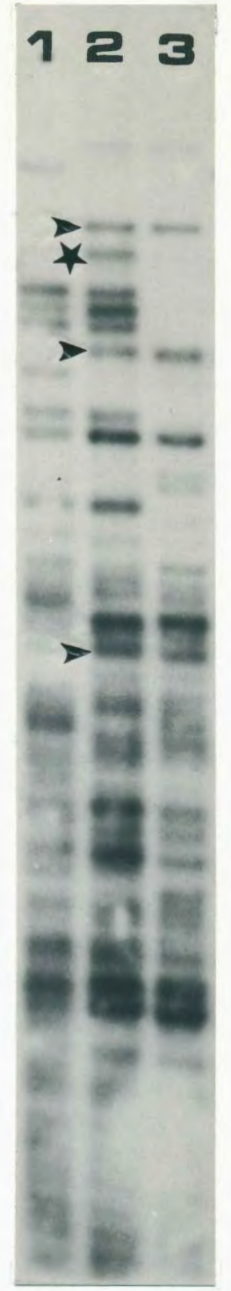

Figure 9 . Paternity determination of a test case using pV47-2. Lane 1 is a fingerprint of the dam (Sid), lane 2 is a fingerprint of the calf (Roman), and lane 3 is a fingerprint of one potential sire (Hugo). Obligate paternal fragments are indicated by a

- symbol. The unique fragment is indicated by a $\star$ symbol. 
TABLE IX

FRAGMENT SHARING PROPORTIONS FOR ASIAN ELEPHANTS USED IN THIS STUDY USING pV47-2 COMPARED ACROSS FUM TWO

\begin{tabular}{lllllllllllll} 
A & B & C & D & E & F & G & H & I & J & K & L & M \\
\hline
\end{tabular}

$\begin{array}{llllllll}R & P & J & B & \text { e } & T & T\end{array}$

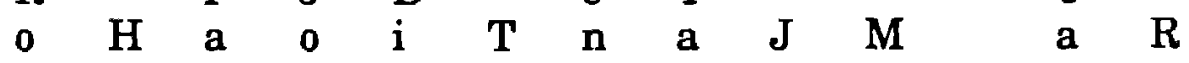

$\begin{array}{lllllllllllll}\mathbf{m} & \mathbf{u} & \mathbf{c} & \mathbf{s} & \mathbf{r} & \mathbf{i} & \mathbf{n} & \mathbf{d} & \mathbf{u} & \mathbf{a} & \mathbf{P} & \mathbf{m} & \mathbf{0}\end{array}$

$\begin{array}{lllllllllllll}a & g & \mathbf{k} & \mathbf{k} & \mathbf{k} & \mathbf{n} & \mathrm{e} & \mathrm{j} & \mathrm{d} & \mathrm{l} & \mathrm{e} & \mathrm{b} & \mathrm{s}\end{array}$

$\begin{array}{lllllllllllll}n & 0 & y & y & a & a & y & i & y & a & t & a & e\end{array}$

$\begin{array}{llllllllllllll}\text { 1. Sid } & .62 & .18 & .15 & .28 & .31 & .21 & .50 & .15 & .27 & .43 & .17 & .28 & .00\end{array}$

$\begin{array}{lllllllllllll}\text { 2. Roman } & .53 & .12 & .42 & .23 & .40 & .62 & .35 & .31 & .33 & .36 & .44 & .12\end{array}$

$\begin{array}{llllllllllll}\text { 3. Hugo } & .35 & .57 & .33 & .40 & .36 & .17 & .57 & .31 & .00 & .13 & .12\end{array}$

$\begin{array}{lllllllllll}\text { 4. Packy } & .25 & .14 & .35 & .31 & .43 & .25 & .27 & .40 & .25 & .22\end{array}$

5. Josky

$\begin{array}{lllllllll}.25 & .42 & .40 & .37 & .44 & .23 & .40 & .47 & .13\end{array}$

6. Birka

$\begin{array}{llllllll}.23 & .15 & .00 & .37 & .67 & .15 & .40 & .61\end{array}$

7. Tina

$\begin{array}{lllllll}.37 & .35 & .42 & .33 & .25 & .22 & .37\end{array}$

8. Jenney

$\begin{array}{llllll}.46 & .40 & .28 & .33 & .28 & .00\end{array}$

9. Tadji

$\begin{array}{lllll}.37 & .13 & .31 & .40 & .15\end{array}$

10. Judy

$\begin{array}{llll}.35 & .40 & .12 & .53\end{array}$

11. Mala

$\begin{array}{lll}.14 & .37 \quad .43\end{array}$

12. Pet

$.31 \quad .13$

13. Tamba

* = First Degree Relatives 


\section{DISCUSSION}

\section{DNA FINGERPRINTING IN ASIAN ELEPHANTS}

DNA fingerprinting studies have been reported for 26 different species using seven different hypervariable probes, including M13. Data reported on the number of fragments scored and the variability of fingerprints of 13 of these species using the seven different probes are summarized in Table X. No data have been reported for hypervariable probe $\mathrm{pV47-2}$. The mean number of fragments scored for all species for all probes reported was $13.4( \pm 1.06)$, varying from five in corn buntings (Miliaria calandra) using Jeffreys' probe 33.6, to 25.5 in the rook (Corvus frugilegus) using Jeffreys' probe 33.15 (Table $\mathrm{X}$ ). In this study, the mean number of fragments scored for the Asian elephant was $8.0( \pm .40)$ using the M13 probe and 8.2 ( \pm .34$)$ using the $\mathrm{pV47-2}$ probe. The number of fragments scored in the elephant with these two probes is lower than the overall average for other reported studies. Data for the M13 probe have been reported for four others species: dogs (Canis familiaris), horses (Equus caballus), cattle (Bos taurus), and pigs (Sus scrofa). The average number of fragments scored in Asian elephants was similar to the number scored in cattle (7.5) and horses (8.0), but lower than that for dogs (14.0) and pigs (11.0). Investigators of other species were able to score DNA fragments down to $2 \mathrm{~kb}$ in size. In this study, fragments became too numerous to score below $3 \mathrm{~kb}$. This could be the reason the number of fragments in the elephant seemed low. The discriminatory power of DNA fingerprinting is 
TABLE X

\section{SUMMARY OF DATA REPORTED ON MEAN NUMBER OF FRAGMENTS SCORED AND MEAN PROPORTION OF FRAGMENTS SHARED FOR 13 SPECIES WITH SIX DIFFERENT HYPERVARIABLE PROBES}

\begin{tabular}{|c|c|c|c|c|c|c|c|}
\hline \multirow{2}{*}{ SPECIES } & & \multicolumn{6}{|c|}{ PROBES } \\
\hline & & M13 & 33.6 & 33.15 & pUCJ & P 3'HVR64 & PSP2.5R1 \\
\hline Human ${ }^{1}$ & $\mathbf{x}$ & & 14 & 15 & & & \\
\hline Homo sapiens & $\mathbf{y}$ & & .25 & .27 & & & \\
\hline Patas monkey ${ }^{2}$ & $\mathbf{x}$ & & & 15 & & & \\
\hline Erythrocebus patas & $\mathbf{y}$ & & & .37 & & & \\
\hline $\operatorname{Dogs}^{3,4}$ & $\mathbf{x}$ & 14 & 16 & 19 & & & \\
\hline Canis familiaris & $\mathbf{y}$ & .43 & .46 & .46 & & & \\
\hline Cats $^{3}$ & $\mathbf{x}$ & & 8 & 13 & & & \\
\hline Felis domesticus & $\mathbf{y}$ & & .47 & .47 & & & \\
\hline Cattle 4 & $\mathbf{x}$ & 7.5 & & & 7.5 & 8.5 & \\
\hline Bos taurus & $\mathbf{y}$ & .35 & & & .36 & .33 & \\
\hline Horses 4 & $\mathbf{x}$ & 8.0 & & & 21.3 & & 11 \\
\hline Equus caballus & $\mathbf{y}$ & .46 & & & .76 & & .27 \\
\hline Pigs $^{4}$ & $\mathbf{x}$ & 11 & & & 13 & & 6 \\
\hline Sus scrofa & $\mathbf{y}$ & .56 & & & .63 & & .68 \\
\hline House sparrows 5 & $\mathbf{x}$ & & 6 & 15 & & & \\
\hline Passer domesticus & $y$ & & .28 & .17 & & & \\
\hline Pied flycatcher 5 & $\mathbf{x}$ & & 8 & $\mathbf{2 2}$ & & & \\
\hline Ficedula hypoleuca & $\mathbf{y}$ & & .13 & .27 & & & \\
\hline Corn bunting 5 & $\mathbf{x}$ & & 5 & 15.5 & & & \\
\hline Miliaria calandra & $\mathbf{y}$ & & .42 & .20 & & & \\
\hline European bee eater ${ }^{5}$ & $\mathbf{x}$ & & $\mathbf{2 3}$ & & & & \\
\hline Apiaster merops & $\mathbf{y}$ & & .30 & & & & \\
\hline Rook $^{5}$ & $\mathbf{x}$ & & & 25.5 & & & \\
\hline Corvus frugilegus & $\mathbf{y}$ & & & .28 & & & \\
\hline Japanese quail ${ }^{5}$ & $\mathbf{x}$ & 8.2 & & & & & \\
\hline $\begin{array}{l}\text { Coturnix coturnix } \\
\text { japonica }\end{array}$ & $\mathbf{y}$ & .30 & & & & & \\
\hline$x=$ mean number of & $\mathrm{gm}$ & ts scor & & $\bar{y}$ & mean $p$ & portion of fra & ents shared. \\
\hline 1 Jeffreys et al. 19 & & & & & & & \\
\hline${ }^{2}$ Weiss et al. 1988 & & & & & & & \\
\hline 3Jeffreys \& Mortc & & & & & & & \\
\hline${ }^{4}$ Georges et al. 19 & & & & & & & \\
\hline 5irke \& Bruford & & & & & & & \\
\hline
\end{tabular}


generally increased with greater numbers of fragments. The resolution of additional small fragments with different probes in elephant fingerprints may increase the power of this technique.

Although the number of fragments scored may influence the usefulness of DNA fingerprinting, the variability between individual fingerprints is a more important factor. The average proportion of fragments shared for unrelated individuals in all species for all probes which have been reported is 0.40 ( \pm .03 ), ranging from 0.13 in pied flycatchers (Ficedula hypoleuca) using Jeffreys' probe 33.6 to 0.76 in horses using probe pUCJ (Table X). The proportion of fragment sharing between unrelated Asian elephants was $0.26( \pm .01)$ for the M13 probe and 0.30 ( \pm .01$)$ for the pV47-2 probe. The variability between elephant fingerprints was therefore relatively high. High variability levels have been found in humans (0.27), house sparrows $(0.17)$, pied flycatchers $(0.27)$, and rooks (0.28) using Jeffreys' probe 33.15. For M13, Asian elephants exhibit the highest variability. Cattle are the next highest in variability at 0.35 .

The number of fragments scored and the proportion of fragment sharing within most species varied considerably between probes. For example, corn buntings showed a mean of five fragments with 0.42 fragment sharing using Jeffreys' 33.6 probe, but 15.5 fragments with 0.20 fragment sharing with Jeffreys' probe 33.15. The most consistent values were found in cattle, which were found to be similar across three different probes. Values for Asian elephant fingerprints were also very similar for the two probes used in this study. 


\section{PATERNITY DETERMINATION IN ASIAN ELEPHANTS BY} DNA FINGERPRINTING

The verification of paternity of a calf of known parentage in this study suggests that DNA fingerprinting can be a useful tool in paternity determination in Asian elephants. DNA fingerprints had adequate variability between individuals and demonstrated the expected inheritance patterns as found in other species. In other words, all fragments in the calf were traceable either to the dam or to the sire. Had the paternity of this calf been unknown, this technique would have correctly excluded the unrelated male in this study from paternity.

It was not possible to conclusively determine paternity in the test case. Unfortunately, a blood sample was obtainable from only one of the two potential sires. Although seven out of nine obligate paternal fragments detected in the calfs fingerprint using both probes were found in the male tested, two fragments were unique to the calf and not present in this male. Unique fragments have been reported in human and bird DNA fingerprints. Out of 344 human offspring studied, 39 were found to have unique fragments not traceable to either parent (Jeffreys et al. 1988). In birds, fragments of new length were also detected in four out of 11 willow warbler (Phylloscopus trochilus) broods (Gyllenstein et al. 1989). Unique fragments are thought to arise from mutations (Jeffreys $1985 \mathrm{a}, \mathrm{b}$ ). The mutation rate for human minisatellite DNA was originally estimated to be $1 \times 10^{-3}$ per DNA fragment per gamete (Jeffreys 1985a). Recent estimates have put the mutation rate higher, up to $5.2 \%$ per kilobase of minisatellite DNA for the most highly mutable human minisatellites (Jeffreys et al. 1988). Slightly higher (5.6\% per gamete) mutation rates have been 
estimated for bird minisatellites (Gyllenstein et al. 1989). It is hypothesized that the mutations are the result of a change in minisatellite length in the germline, presumably from unequal crossover events (Jeffreys et al. 1988). The mutation rate for elephant DNA is unknown. If one assumes that it is similar to that estimated for humans and birds, it is not unlikely that a new length minisatellite fragment could arise in an offspring.

In this particular case, two unique fragments were detected. Each probe detected only one of these. It is unlikely that two mutations would occur in the same gamete. However, both fragments were similar in size and may be identical. DNA fingerprints using the M13 and pV47-2 probes are not identical but do appear to be similar. Due to the fact that the pV47-2 probe was originally derived from M13, detection of some identical fragments would not be surprising. Other investigators have also seen a high degree of similarity between both M13 and pV47-2 fingerprints in some species, although not all (O. Ryder, personal communication). If both probes are detecting the same mutation, the male which was tested might indeed be the sire. This male has been presumed to be the sire by zoo personnel due to a physical resemblance to the offspring. At this point, however, no conclusive determination can be made on the basis of DNA fingerprinting without testing the second male. It is interesting to note that the unrelated male in the control test shared two of the three obligate paternal fragments. Thus, a one fragment difference in that case was all that differentiated the true sire from an unrelated male.

The second potential sire in this case killed a trainer during an episode of musth. Because of his highly aggressive nature this male could not be handled for blood sampling. It is possible that, in the future, 
additional information could be obtained by testing other offspring from known matings between the unavailable male and various cows. Determination of obligate paternal fragments from the fingerprints of other calves could be used to partially reconstruct the fingerprint of the unavailable male. This type of analysis has been used in human immigration cases where only one parent and several siblings were available (Jeffreys et al. 1985c). This has also been done in primates (Weiss et al. 1988). Several of the animals in this study were sired by a bull who is now deceased. In instances where the dam was still available and maternal fragments could be eliminated, obligate paternal fragments from several individuals were used to partially reconstruct the fingerprint of the deceased bull (Figure 10). This reconstructed fingerprint provided 4 paternal fragments which, had they matched unique fragments in a calf, could have helped determine paternity. This type of analysis could perhaps be used in the future to gain additional information in the unresolved test case.

\section{ESTIMATION OF RELATEDNESS BY DNA FINGERPRINTING}

Given the heritability of minisatellite fragments, it has been hypothesized that fragment sharing proportions can be used to determine relatedness when pedigrees are unknown. When heterozygosity is high, first degree relatives are expected to share $50 \%$ of their fragments, while second degree relatives are expected to share $25 \%$ (Wetton et al. 1987). Wetton used this hypothesis to confirm parentage in a population of wild house sparrows. He found that individuals within broods had a mean 


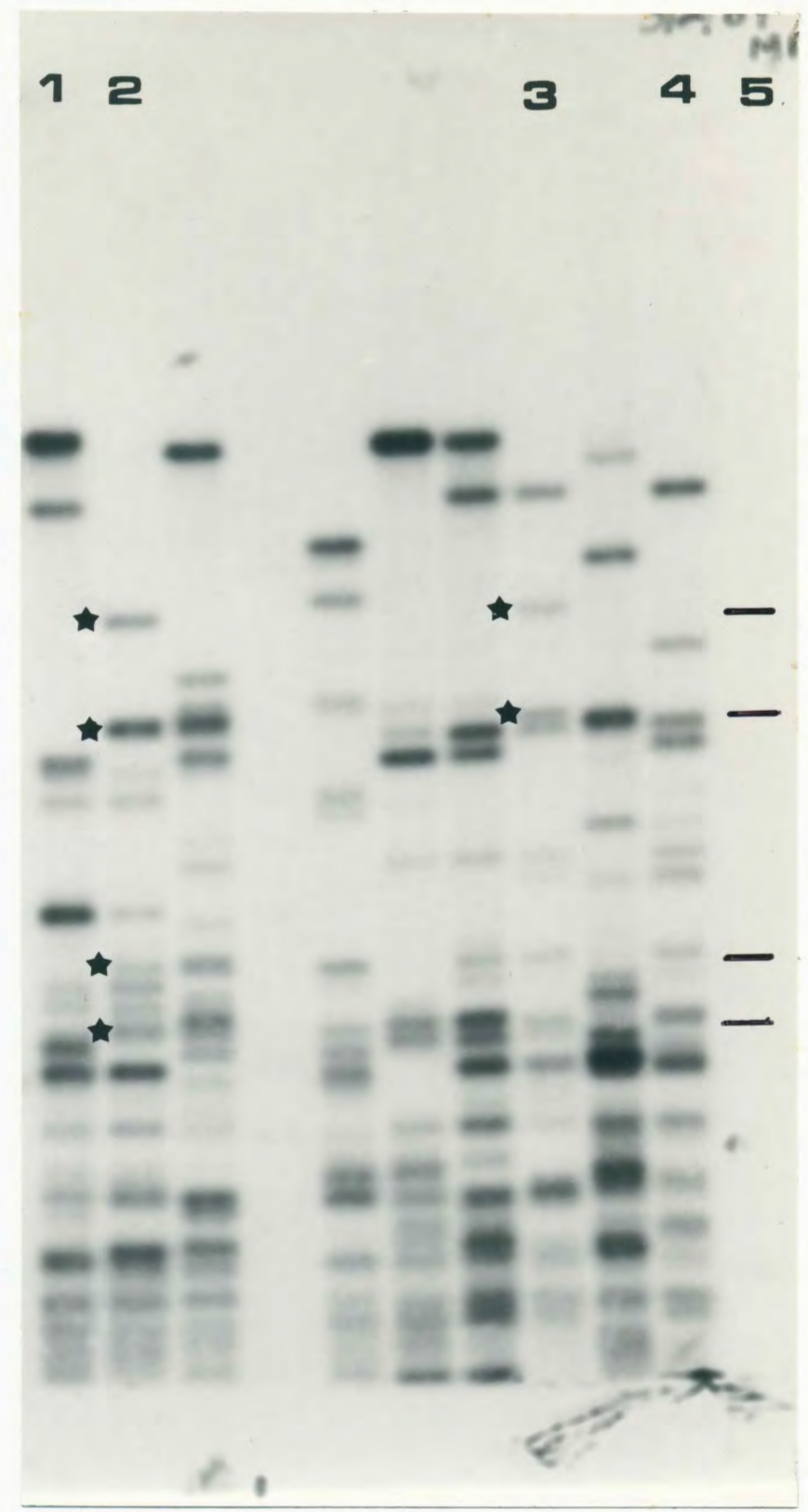

Figure 10. Partial reconstruction of the DNA fingerprint of a deceased male by examination of his calves and their dams. Lanes 1 and 4 are dams, lanes 2 and 3 are their respective calves, and lane 5 is the reconstructed fingerprint of the deceased sire. Obligate paternal fragments are indicated by a symbol. 
fragment sharing score of 0.47 , close to the expected value of 0.50 .

Individuals from different broods shared less than 0.25. One instance of incorrect paternity was suspected when a low score $(0.36)$ between an offspring and its putative father was found. Direct paternity analysis revealed that the bird in question was the offspring of another male, with which it shared $72 \%$ of its fragments. High fragment sharing scores were hypothesized to arise from incestuous matings. Wetton concluded that the proportion of fragment sharing could be used as a guide to determine relatedness in wild populations.

African elephants (Loxodonta africana) in the wild have been reported to live in matriarchal societies where females associate together in family units and males are solitary. Separate family units which associate often are also assumed to be related (Douglas-Hamilton 1975, Moss 1988). Several investigators have expressed an interest in using DNA fingerprinting to determine if Asian elephants in close association are related. The proportion of fragment sharing between Asian elephants in this study for first degree relatives, second and third degree relatives, and unrelated animals was $0.62( \pm .04), 0.46( \pm .03)$, and 0.26 ( \pm .01$)$, respectively for $\mathrm{M} 13$, and 0.65 ( \pm .06$), 0.54( \pm .06)$, and 0.30 ( \pm .01$)$ for $\mathrm{pV47-2}$. Using pV47-2, the difference in fragment sharing values between unrelated animals and first degree relatives was statistically significant (KruskalWallis one-way analysis of variance, $p<.01$ ). However, the actual distribution of scores shows a large area of overlap (Figure 11). Pairs of animals in all relatedness categories were found in the range between 0.22 and 0.67 . The use of probe M13 improved the resolution of relatedness 
$\frac{0}{0}$
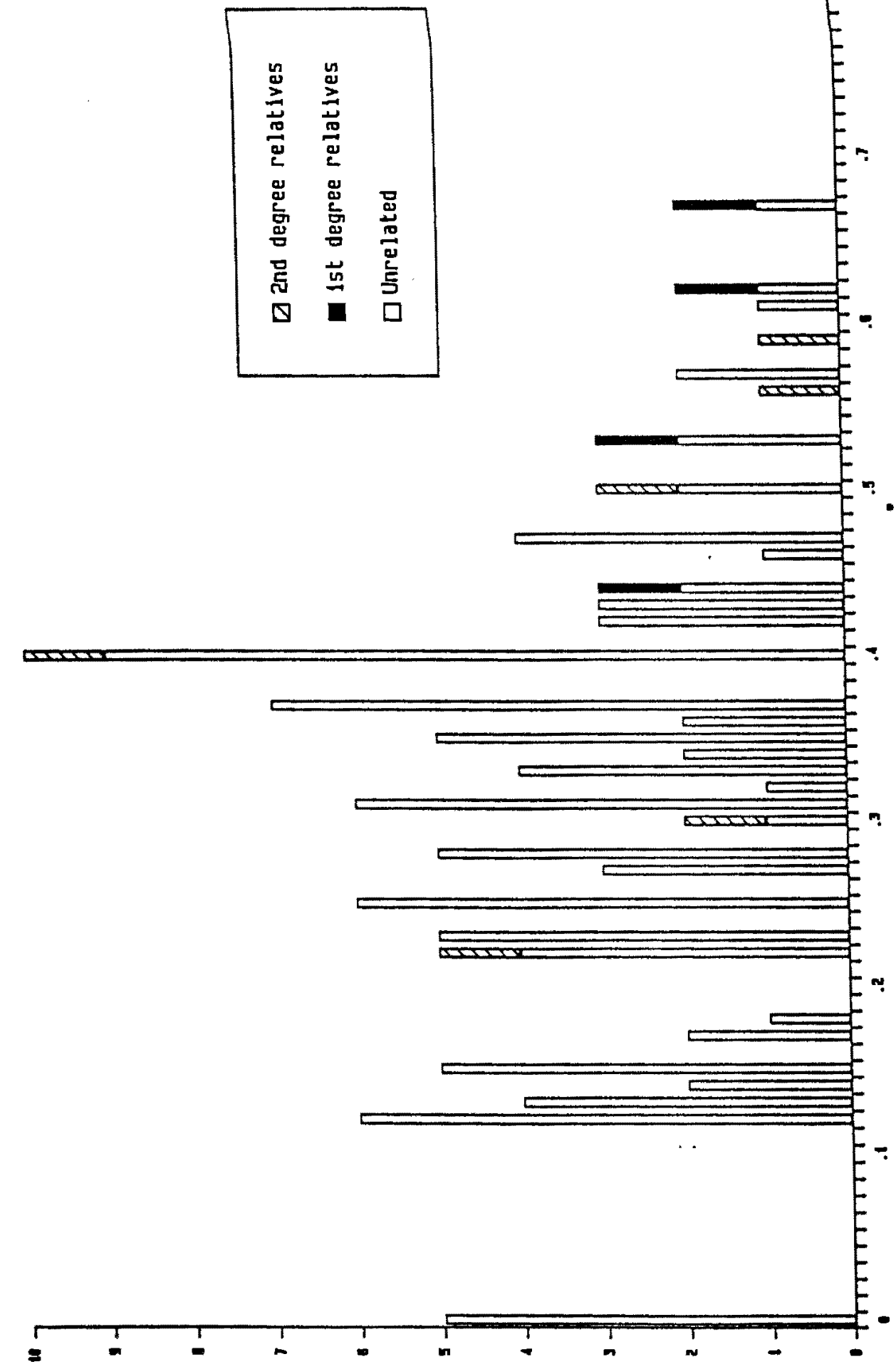

뭉 
categories. Differences in fragment sharing between unrelated animals and first degree relatives and also between unrelated animals and second and third degree relatives were significant using M13 (Kruskal-Wallis oneway analysis of variance, $p<.01$ ). The distribution of scores by relatedness category also showed an area of overlap (Figure 12); however, this area was smaller than that shown by pV47-2, ranging between 0.35 and 0.60 . The most significant overlap appeared to occur between 0.47 and 0.59 . The M13 probe, therefore, is the most effective of the two probes in distinguishing relatedness. It appears that this technique can be an accurate estimator of relatedness in the extreme ranges. Animals with less than 0.35 of their fragments in common can be assumed to be unrelated, while animals sharing more than 0.60 can be assumed to be related. Given that the use of M13 narrowed the overlap zone and improved discrimination of relatedness categories over $\mathrm{pV} 47-2$, it is probable that other probes could be found which could further improve the effectiveness of this technique.

Lynch (1988) calculated that in an extreme case of 25 loci with an infinite number of alleles, the standard error of relatedness estimates would be $14 \%, 20 \%, 35 \%$, and $53 \%$ of the expectation for first, second, third, and fourth degree relationships, respectively. Given these error factors, it is not surprising that the fragment sharing proportions of elephants overlap. It is also conceivable that the elephants used for this study belong to separate subspecies which share different allele frequencies. This could contribute to the overlap of fragment sharing values. There are, however, no data to support this latter hypothesis. Accordingly, it would be inadvisable to use this technique alone for absolute relatedness determinations when no other data are available. On the other hand, DNA 


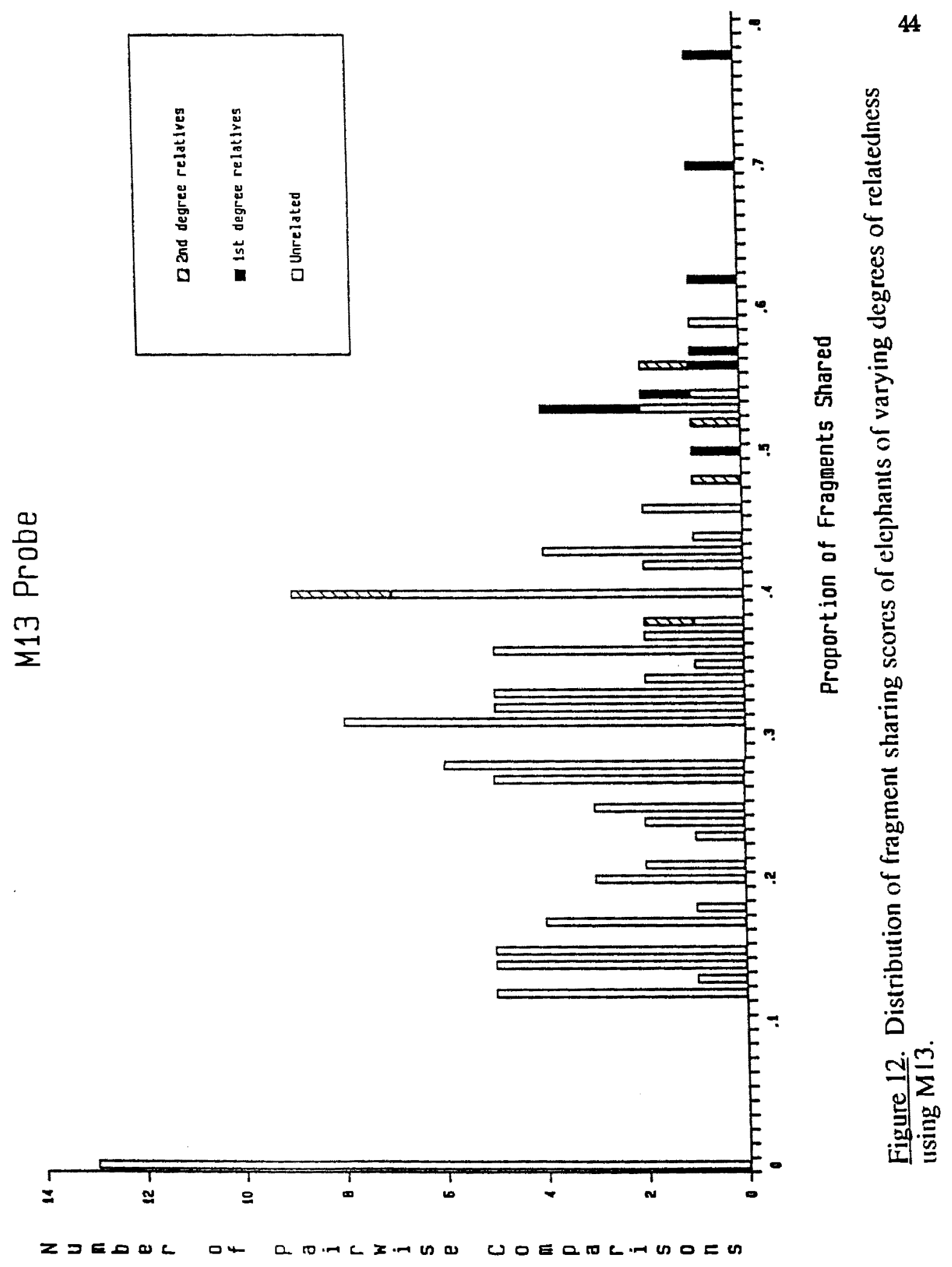


fingerprinting could be very effectively used to gather supportive evidence where first degree relationships are indicated from behavioral or other data. 


\section{CONCLUSIONS}

DNA fingerprinting can be a useful tool in the management and study of Asian elephants if it is used with caution. Asian elephant DNA fingerprints have a relatively high level of variability. This technique can be effectively used for paternity ascertainment when all potential sires can be tested, but must be used with caution when all potential sires are not available. DNA fingerprinting may also be used for estimating relatedness between elephants. It is important, however, to determine the effective range of a probe on a control group before attempting to establish the degree of relatedness in the wild using DNA fingerprinting alone. In this study, M13 proved to be the most effective probe for determining the degree of relatedness, with fragment sharing scores of less than 0.35 indicating unrelated animals and fragment sharing scores greater than 0.60 indicating related animals. Further research will presumably reveal new probes which will increase the discriminatory power of this technique for use on Asian elephants. 


\section{REFERENCES}

Alexander, S. 1983. The man who loved elephants. Pacific Northwest. 70:28-33.

American Association of Zoological Parks and Aquariums. 1989. Asian Elephant Species Survival Masterplan. AAZPA, Wheeling, West Virginia.

Bell, G. I., Selby, M. J., \& Rutter, W. J. 1982 . The highly polymorphic region near the human insulin gene is composed of simple tandemly repeating sequences. Nature. 295:31-35.

Bouman, J. 1977. The future of Przewalski horses. Intl. Zoo Yrbk. 17:62-68.

Burke, T., \& Bruford, M. W. 1987. DNA fingerprinting in birds. Nature. 327:149-152.

Dixson, A. F., Hastie, N., Patel, I., \& Jeffreys, A. J. 1988. DNA 'fingerprinting' of captive family groups of common marmosets (Callithrix jacchus). Folia primatol. 51:52-55.

Dobias, R. J. 1987. Elephants in Thailand: an overview of their status and conservation. Tigerpaper. 14:19-24.

Douglas-Hamilton, I., \& Douglas-Hamilton, O. 1975 Among the Elephants. The Book Press, Brattleboro, Vermont, p. 58.

Flesness, N. R. 1977. Gene pool conservation and computer analysis. Intl. Zoo Yrbk. 17:77-81.

Foose, T. J. 1983. The Relevance of Captive Populations to the Conservation of Biotic Diversity. In Genetics and Conservation: A Reference for Managing Wild Animal and Plant Populations, Schonewald-Cox, C. M., Chambers, S. M., MacBryde, B., \& Thomas, L., eds. Benjamin/Cummings Pub. Co., Inc., Menlo Park, California, pp.374-401.

Georges, M., Lequarre, A.-S., Castelli, M., Hanset, R., \& Vassart, G. 1988a. DNA fingerprinting in domestic animals using four different minisatellite probes. Cytogenet. Cell Genet. 47:127-131. 
Georges, M., Hilbert, P., Lequarre, A.-S., Leclerc, V., Hanset, R., \& Vassart, G. 1988b. Use of DNA bar codes to resolve a canine paternity dispute. JAVMA 193 (9):1095-1089.

Goodbourn, S. E. Y., Higgs, D. R., Clegg, J. B., Weatherall, D. J. 1983. Molecular basis of length polymorphism in the human globin gene complex. Proc. Nat'l. Acad. Sci. USA. 80:5022-5026.

Gyllenstein, U. B., Jakobsson, S., Temrin, H., \& Wilson, A. C. 1989.

Nucleotide sequence and genomic organization of bird minisatellites.

Nucleic Acids Research. 17(6):2203-2214.

Henneous, R., Schmidt, M., \& Haight, J. 1987. Deadly dilemmas of captive elephant breeding. In American Association of Zoological Parks and Aquariums annual conference proceedings, pp. 135-139.

Jarman, A. P., Nicholls, R. D., Weatherall, D. J., Clegg, J. B., \& Higgs, D. R. 1986. Molecular characterization of a hypervariable region downstream of the human $\alpha$-globin gene cluster. EMBO J. 5:1857-1863.

Jeffreys, A. J., Wilson, V., \& Thein, S. L. 1985a. Hypervariable 'minisatellite' regions in human DNA. Nature. 314:67-73.

Jeffreys, A. J., Wilson, V., \& Thein, S. L. 1985b. Individual-specific 'fingerprints' of human DNA. Nature. 316:76-79.

Jeffreys, A. J., Brookfield, J. F. Y., \& Semeonoff, R. 1985c. Positive identification of an immigration test-case using human DNA fingerprints. Nature. 317:818-819.

Jeffreys, A. J., \& Morton, D. B. 1987. DNA fingerprints of dogs and cats. Animal Genetics. 18:1-15.

Jeffreys, A. J., Royle, N. J., Wilson, V., \& Wong, Z. 1988. Spontaneous mutation rates to new length alleles at tandem-repetitive hypervariable loci in human DNA. Nature. 332:278-281.

Keele, M. 1989. Asian Elephant Regional Studbook. Washington Park Zoo, Portland, Oregon.

Kurt, F. 1970. A comparison of reproduction in tame and wild elephants.

I.U.C.N. xI Technical Meeting. 1:148-154. 
Kurt, F. 1974. Remarks on the social structure and ecology of the Ceylon elephant in the Yala National Park. In The Behavior of Ungulates and its Relation to Management, I.U.C.N., Morges, Switzerland. pp. 618-634.

Lasley, J. F. 1978. Genetics of Livestock Improvement. Prentice-Hall, Englewood Cliff, New Jersey.

Linnaeus. 1758. Syst. Nat. 10th ed. 1:33.

Lumpkin, S., \& Seidensticker, J. 1987. Elephants at war. Zoogoer. 16:4-8.

Lynch, M. 1988. Estimation of relatedness by DNA fingerprinting. Mol. Biol. Evol. 5(5):584-599.

Maberry, M. B. 1962. Breeding Indian elephants (Elephas maximas) at the Portland Zoo. Intl. Zoo Yrbk. 4:80-83.

Maniatis, T., Fritsch, E. F., \& Sambrook, J. 1982 Molecular Cloning. Cold Spring Harbor Laboratory, Cold Spring Harbor, New York, 545 pp.

Moss, C. 1988. Elephant Memories. Ballantine Books, USA, pp. 32-33.

Olivier, R. 1978. Distribution and status of the Asian elephant. Oryx. 13:379-424.

Proudfoot, N. J., \& Maniatis, G. A. 1982. The structure of the human zetaglobin gene and a closely linked, nearly identical pseudogene. Cell. 31:555-563.

Ralls, K. \& Ballou, J. 1982a. Effects of inbreeding on infant mortality in captive primates. Intl. Jrnl. of Primatol. 3(4):491-505.

Ralls, K., \& Ballou, J. 1982b. Inbreeding and juvenile mortality in small populations of ungulates: a detailed analysis. Biol. Conserv. 24:239:272.

Ralls, K., \& Ballou, J. 1983. Extinction: Lessons from Zoos. In Genetics and Conservation: A Reference for Managing Wild Animal and Plant Populations. Schonewald-Cox, C. M., Chambers, S. M., MacBryde, B., \& Thomas, L., eds. Benjamin/Cummings Pub. Co. Inc., Menlo Park, California, pp. 164-184.

Ralls, K., Brugger, K., \& Ballou, J. 1979. Inbreeding and juvenile mortality in small populations of ungulates. Science. 206:1101-1103. 
Ralls, K., Brugger, K., \& Glick, A. 1980. Deleterious effects of inbreeding in a herd of captive Dorcas gazelle. Intl. Zoo Yrbk. 20:137-146.

Seidensticker, J. 1984. Managing elephant depredation in agricultural and forestry projects. A World Bank Technical Paper, 33 pp.

Southern, E. M. 1975. Detection of specific sequences among DNA fragments separated by gel electrophoresis. J. Mol. Biol. 98:503-517.

Templeton, A. R., \& Read, B. 1983. The elimination of inbreeding depression in a captive herd of Speke's gazelle. In Genetics and Conservation: A Reference for Managing Wild Animal and Plant Populations. Schonewald-Cox, C. M., Chambers, S. M., MacBryde, B., \& Thomas, L., eds. Benjamin/Cummings Pub. Co. Inc., Menlo Park, California, pp. 241-261.

Templeton, A. R., \& Read, B. 1984. Factors eliminating inbreeding depression in a captive herd of Speke's gazelle. Zoo Biol. 3:177-199.

Vassart, G., Georges, M., Monsieur, R., Brocas, H., Lequarre, A.-S., \& Christophe, D. 1987. A sequence in M13 phage detects hypervariable minisatellites in human and animal DNA. Science. 235:683-684.

Weiss, M. L., Wildon, V., Chan, C., Turner, T., \& Jeffreys, A. J. 1988. Application of DNA fingerprinting probes to Old World monkeys. American Jrnl. of Primatology. 16:73-79.

Westneat, D. F., Noon, W. A., Reeve, H. K., \& Aquadro, C. F. 1988. Improved hybridization conditions for DNA 'fingerprints' probed with M13. Nucleic Acids Research. 16(9): 4161.

Wetton, J. H., Carter, R. E., Parkin, D. T. 1987. Demographic study of a wild house sparrow population by DNA fingerprinting. Nature. 327:147-149.

Wright, S. 1977. Inbreeding in animals: Differentiation and depression. In Evolution and the Genetics of Populations, Vol. 3, Experimental Results and Evolutionary Deductions. University of Chicago Press, Chicago, Illinois, pp. 44-96.

Wyman, A., \& White, R. 1980. A highly polymorphic locus in human DNA. Proc. Nat'l. Acad. Sci. USA. 77:6754-6758. 


\section{APPENDIX A}

\section{TOTAL DNA EXTRACTION FROM WHOLE BLOOD}

1. Centrifuge approximately $10 \mathrm{ml}$ whole blood at $1500 \mathrm{x}$ g for $15 \mathrm{~min}$.

2. Pipet off upper plasma layer and discard.

3. Pipet off upper white cell layer and transfer to polypropylene tube.

4. Add $0.9 \% \mathrm{NaCl}$ to white cells and bring to original volume. Resuspend. Centrifuge at $1400 \times \mathrm{g}$ for $15 \mathrm{~min}$. Pipet off supernatant and discard. Repeat until supernatant is clear.

5. Resuspend pellet in 5.5 times the pellet volume of cold haemolysis solution (9:1 0.144 $\mathrm{M} \mathrm{NH}_{4} \mathrm{Cl}, 0.010 \mathrm{M} \mathrm{NH}_{4} \mathrm{HCO}_{3}$ ).

6. Place at $-20^{\circ} \mathrm{C}$ for $3 \mathrm{~min}$. or until color turns from red to wine. Centrifuge at $1400 \mathrm{xg}$ for $20 \mathrm{~min}$. Pipet off supernatant and discard. Repeat until red blood cell contamination is negligible.

7. Resuspend pellet in STE ( $10 \mathrm{mM}$ Tris- $\mathrm{HCl} \mathrm{pH} 8.0,100 \mathrm{mM} \mathrm{NaCl}$, $1 \mathrm{mM}$ EDTA pH 8.0) to a volume of $6 \mathrm{ml}$.

8. Add $500 \mu$ proteinase $\mathrm{K}\left(1 \mathrm{mg} / \mathrm{ml}\right.$ in $\mathrm{H}_{2} \mathrm{O}$ ) while mixing gently. Slowly add $200 \mu 25 \%$ SDS while mixing gently. Incubate at $37^{\circ} \mathrm{C}$ 16-20 hours.

9. Add an equal volume of PCIA (Tris-buffered phenol chloroform, prepared according to Maniatis et al. 1982). Mix gently for $15 \mathrm{~min}$. Centrifuge at $1600 \mathrm{xg}$ for $20 \mathrm{~min}$.

10. Transfer upper DNA layer to new tube. Repeat PCIA extraction two more times.

11. Repeat above extraction with CIA (chloroform:isoamyl alcohol 24:1).

12. Add $1 / 10$ volume sodium acetate ( $\mathrm{pH}$ 5.2). Add 3 volumes cold absolute ethanol. Place at $-20^{\circ} \mathrm{C}$ overnight.

13. Centrifuge at $4^{\circ} \mathrm{C} 10,000 \times \mathrm{g}$ for $40-50 \mathrm{~min}$. Discard supernatant. 
14. Rinse pellet with $75 \%$ ethanol. Centrifuge $10,000 \times \mathrm{g}$ for $20 \mathrm{~min}$. Discard supernatant.

15. Vacuum dry pellet.

16. Resuspend pellet in approximately $400 \mu \mathrm{lE}$ (10 mM Tris-HCl pH 8.0, 1 mM EDTÁ pH 8.0). 


\section{APPENDIX B \\ MODIFIED SOUTHERN BLOT PROCEDURE FOR DNA FINGERPRINTING}

1. Soak gel in $0.25 \mathrm{M} \mathrm{HCl}$ on shaker for 1 hour.

2. Replace $0.25 \mathrm{M} \mathrm{HCl}$ with denaturing solution (1.50 M NaCl, $0.50 \mathrm{M} \mathrm{NaOH}$ ) and soak on shaker for $45 \mathrm{~min}$.

3. Replace denaturing solution with neutralizing solution (1.50 M NaCl, $0.50 \mathrm{M}$ Tris- $\mathrm{HCl} \mathrm{pH} 7.2,1 \mathrm{mM}$ EDTA) and shake gently for $45 \mathrm{~min}$.

4. Pour off solution and blot gel dry with Kimwipes.

5. Wet a piece of $3 \mathrm{MM}$ Whatman filter paper with once distilled water and place in gel rig. Paper should be the exact width of the rig but long enough to form wicks between buffer reservoirs.

6. Place gel upside-down on top of paper. Make sure there are no air bubbles beneath the gel.

7. Place nylon membrane on gel where transfer is desired, trapping no air bubbles beneath.

8. Wet two pieces of $3 \mathrm{MM}$ Whatman filter paper (exact size as gel) and place on top of the membrane, trapping no air bubbles beneath.

9. Stack 4-5 cm of single fold paper towels on top of paper, trapping as little air as possible.

10. Place a Pyrex dish filled with water on top of paper towels for weight.

11. Fill buffer reservoirs with $20 \mathrm{XSSC}(3 \mathrm{M} \mathrm{NaCl}, 0.3 \mathrm{M}$ sodium citrate) so that wicks are immersed.

12. Allow transfer to proceed overnight.

13. Rinse membrane briefly with $2 \mathrm{X}$ SSC and allow to dry on Saran wrap. 
14. Wrap membrane in Saran wrap and place DNA side down on UV transilluminator for 5-8 $\mathrm{min}$.

15. Wet membrane briefly in 5X SSC. Place in heatseal bag with $20 \mathrm{mls}$ of prehybridization solution (7\% SDS, 1 mM EDTA pH 8.0, 0.263 M $\mathrm{Na}_{2} \mathrm{HPO}_{4}, 1 \% \mathrm{BSA}$ ). Remove air bubbles from bag, double seal and gently shake in $60^{\circ} \mathrm{C}$ water bath overnight.

16. Remove prehybridization solution from bag. Replace with $20 \mathrm{mls}$ of hybridization solution ( $=$ fresh prehybridization solution to which $200 \mathrm{ng}$ radiolabelled probe has been added). Remove bubbles and double seal. Place in shielded container in $60^{\circ} \mathrm{C}$ water shaker-bath overnight.

17. Remove membrane from bag and place in plastic container. Cover with $2 \mathrm{X} \mathrm{SSC} / 0.1 \%$ SDS and shake gently at room temperature for $15 \mathrm{~min}$.

18. Decant solution and repeat.

19. Repeat wash as above for $15 \mathrm{~min}$. in $60^{\circ} \mathrm{C}$ water.

20. Rinse membrane briefly with 1X SSC. Wrap in Saran wrap.

21. Place membrane in cassette with Fuji $x$-ray film and intensifying screens. Store at $-80^{\circ} \mathrm{C}$ for $6-48$ hours before developing.

REMOVAL OF PROBE

Wash membranes in boiling $0.1 \%$ SDS for 15 minutes on shaker. Repeat two more times. 


\section{APPENDIX C}

\section{RADIOLABELLING OF PROBES}

1. Mix $200 \mathrm{ng}$ linearized, single stranded probe DNA (2.5 $\mu \mathrm{l})$ with $4.25 \mu \mathrm{l}$ sterile $\mathrm{H}_{2} \mathrm{O}$. Heat in $100^{\circ} \mathrm{C}$ oil block $2 \mathrm{~min}$. Cool on ice.

2. Add $1 \mu \mathrm{l} \mathrm{BSA}(10 \mathrm{mg} / \mathrm{ml}), 1.25 \mu \mathrm{l}$ primer, and $10 \mu \mathrm{l} 2.5 \mathrm{X}$ reaction buffer containing $d A, T$, and GTP.

3. Add $50 \mu \mathrm{Ci} \alpha^{32} \mathrm{dCTP}$ and $1 \mu \mathrm{l}$ klenow fragment of DNA polymerase I. Leave in lead pig 3-12 hours.

4. Plug a 1 cc syringe with sterile, siliconized glass wool. Place in centrifuge tube and fill with Sephadex G-50 beads which have been equilibrated in TE (10 mM Tris-HCl pH 8.0, $1 \mathrm{mM}$ EDTA).

5. Spin in swinging bucket rotor $2 \mathrm{~min}$. at maximum speed. Refill with G-50 beads and repeat until packed column volume is approximately 0.9 cc.

6. Add TE to column (to rim) and spin through as above 3 times.

7. Add $100 \mu \mathrm{l} \mathrm{TE}$ and spin through 3 times as above. Make sure that $100 \mu \mathrm{l}$ is retrieved from the column after the last spin (collect in an Eppendorf tube placed under syringe).

8. Dilute probe to $100 \mu \mathrm{l}$ with TE and spin through column as above, collecting in a new Eppendorf tube.

9. Replace Eppendorf tube containing probe with a new tube and spin another $100 \mu \mathrm{l}$ of TE through the column. This rinse should register no more than half the cpm of the probe when checked with a Geiger counter from the same distance. 


\section{APPENDIX D}

\section{TRICHLOROACETIC ACID PRECIPITATION OF NUCLEIC ACIDS}

1. Before the addition of DNA polymerase $I$, spot $1 \mu$ of reaction mixture onto a $2 \mathrm{~mm}$ circle of glass fiber chromatography filter paper. Transfer $1 \mu \mathrm{l}$ of reaction mixture into a tube of $10 \mu \mathrm{g}$ salmon sperm DNA in $500 \mu \mathrm{l}$ sterile $\mathrm{H}_{2} \mathrm{O}$ three times during the reaction: once prior to the addition of DNA polymerase I, once at the end of the reaction and once after column separation.

2. Presoak three $2 \mathrm{~mm}$ filters in $10 \% \mathrm{TCA} / 0.02 \mathrm{M} \mathrm{NaPP}$.

3. Set filter spotted before the addition of the polymerase aside. Add $500 \mu \mathrm{l}$ cold $10 \% \mathrm{TCA} / 0.02 \mathrm{M}$ NaPP to each salmon sperm tube. Ice $10 \mathrm{~min}$.

4. Place the other 3 filters on the TCA machine and start the vacuum. Pour contents of tubes onto filters.

5. Rinse filters 3 times in cold $5 \% \mathrm{TCA} / 0.02 \mathrm{M} \mathrm{NaPP}$.

6. $\cdot$ Rinse chimneys 3 times with $5 \%$ TCA/0.02 M NaPP.

7. Remove chimneys. Rinse filters 3 times with 5\% TCA.

8. Rinse filters 3 times with $70 \%$ ethanol.

9. Dry filters under heat lamp and run through a scintillation counter. 